\title{
The Reputational Effects of Analysts' Stock Recommendations and Credit Ratings: Evidence from Operational Risk Announcements in the Financial Industry
}

\author{
Ahmed Barakat*,a ${ }^{*}$ Simon Ashby ${ }^{\mathrm{b}}$, Paul Fenn $^{\mathrm{a} 1}$
}

\begin{abstract}
This paper investigates whether more favorable stock recommendations and higher credit ratings serve as a reputational asset or reputational liability around reputation-damaging events. Analyzing the reputational effects of operational risk announcements incurred by financial institutions, we find that firms with a "Buy" stock recommendation or "Speculative Grade" credit rating are more likely to incur an equity-based reputational damage. In addition, firms with lower credit ratings incur a much more severe debt-based reputational damage. Moreover, credit ratings are more instrumental in mitigating the debt-based reputational damage caused by fraud incidents or incurred in non-banking activities. Furthermore, the misconduct of senior management could demolish the reputation of firms with less heterogeneous stock recommendations. Finally, credit ratings serve as an equity-based reputational asset in the short term but turn into an equity-based reputational liability in the long term. Overall, our analysis reveals that stock recommendations represent a reputational burden and credit ratings act as a reputational shield; however, the persistence and magnitude of such reputational effects are moderated by time and event characteristics.
\end{abstract}

Keywords: Reputational risk, operational risk, financial analysts, stock recommendations, credit ratings, financial institutions

\footnotetext{
* Corresponding author: Industrial Economics and Finance Division, Nottingham University Business School, Jubilee Campus, Nottingham, NG8 1BB. Phone Number: +44(0)1158466643. Email: ahmed.barakat@ nottingham.ac.uk.

a) Industrial Economics and Finance Division, Nottingham University Business School, University of Nottingham.

b) Plymouth Business School, Faculty of Business, Plymouth University.
} 


\title{
The Reputational Effects of Analysts' Stock Recommendations and Credit Ratings: Evidence from Operational Risk Announcements in the Financial Industry
}

\begin{abstract}
This paper investigates whether more favorable stock recommendations and higher credit ratings serve as a reputational asset or reputational liability around reputation-damaging events. Analyzing the reputational effects of operational risk announcements incurred by financial institutions, we find that firms with a "Buy" stock recommendation or "Speculative Grade" credit rating are more likely to incur an equity-based reputational damage. In addition, firms with lower credit ratings incur a much more severe debt-based reputational damage. Moreover, credit ratings are more instrumental in mitigating the debt-based reputational damage caused by fraud incidents or incurred in non-banking activities. Furthermore, the misconduct of senior management could demolish the reputation of firms with less heterogeneous stock recommendations. Finally, credit ratings serve as an equity-based reputational asset in the short term but turn into an equity-based reputational liability in the long term. Overall, our analysis reveals that stock recommendations represent a reputational burden and credit ratings act as a reputational shield; however, the persistence and magnitude of such reputational effects are moderated by time and event characteristics.
\end{abstract}

Keywords: Reputational risk, operational risk, financial analysts, stock recommendations, credit ratings, financial institutions 


\section{INTRODUCTION}

Expert advice is crucial to the discipline of efficient markets. Both individual and institutional investors benefit from expert advice in several forms among the most important of which are equity analysts' stock recommendations (hereafter, stock recommendations) and debt analysts' credit ratings (hereafter, credit ratings). Previous research has documented the incremental informational contents of stock recommendations (Baik \& Park, 2003; Barber, Lehavy, McNichols, \& Trueman, 2001; Jegadeesh \& Kim, 2006; Jiang \& Kim, 2016; Liu, Smith, \& Syed, 1990; Menéndez-Requejo, 2005; Wormac, 1996) and credit ratings (Blanco, Brennan, \& Marsh, 2005; Boot, Milbourn, \& Schmeits, 2006; Chung, Ann Frost, \& Kim, 2012; Creighton, Gower, \& Richards, 2007; Goh \& Ederington, 1993; Hand, Holthausen, \& Leftwich, 1992; Holthausen \& Leftwich, 1986; Hull, Predescu, \& White, 2004; Kliger \& Sarig, 2000; Norden \& Weber, 2004; J. Wang, Svec, \& Peat, 2014). According to these previous studies and many others, stock recommendations drive equity markets and credit ratings affect both equity and debt markets (i.e. bond and credit default swap "CDS" markets). Hence, it can be argued that stock recommendations partially reflect the market risk included in trading a certain stock, whereas credit ratings partially reflect the credit risk or default risk included in trading a certain bond.

Although much literature has focused on the informational contents of stock recommendations and credit ratings and how their bias could affect the efficiency of equity and debt markets, to the best of our knowledge, no previous research has investigated the reputational effects of such expert advice. The major reason for such a lack of this type of research is the obvious difficulty of measuring reputational risk. Hence, we exploit the unique opportunity of the quantifiable reputational damage known to be caused by operational risk announcements in financial institutions ${ }^{2}$ to gauge the incremental reputational effects of stock recommendations and credit ratings beyond any firm-level factors, eventspecific features and announcement-related characteristics.

Our main argument in this paper is that operational risk announcements constitute an unexpected arrival of bad news disclosing the operational loss amount and reflecting the event-causing internal control weaknesses (ICWs) and other relevant firm-level deficiencies. Hence, this adverse idiosyncratic informational shock hitting the financial markets should cause investors to revise their prior beliefs about the expected amounts and probabilities of cash flows (i.e. valuation and creditworthiness) of the loss firm, thus imposing a reputational impact beyond the nominal equity-depleting operational loss amount (Cummins, Lewis, \& Wei, 2006; Gillet, Hübner, \& Plunus, 2010; Plunus, Gillet, \& Huebner, 2012). Since a crucial part of these prior investors' beliefs are inevitably formed by expert advice (i.e. stock recommendations and credit ratings), we argue that such a reputational impact would be partially determined by the loss firm's stock recommendation favorability and credit rating level.

\footnotetext{
${ }^{2}$ See Section 2.1. for a detailed review of the literature on operational and reputational risks in financial institutions.
} 
There are two competing theories in the literature that might explain the reputational effects of stock recommendations and credit ratings around operational risk announcements. First, the "Expectancy Violation Theory" (Rhee \& Haunschild, 2006), whereby the unexpected arrival of bad news would seriously violate prior optimistic investors' expectations, hence, accentuating the adverse reputational effects in firms with more favorable stock recommendations and higher credit ratings. In this case, expert advice would be a reputational burden on the loss firm. Second, the "Institutional Legitimacy" theory (Rhee \& Haunschild, 2006), whereby expert advice provided by well-established institutions (e.g. equity analysts working for brokerage houses and debt analysts in credit rating agencies) gains escalating credibility (i.e. legitimacy) and becomes more difficult to be challenged by less informed investors. Hence, non-expert equity investors would expect firms with more favorable stock recommendations and higher credit ratings to continue to have more robust financial performance and less risky business profile in the future, thus making them more resilient to the adverse consequences of the announced operational risk events and more able to remedy their underlying causes. In this case, expert advice would serve as a reputational asset of the loss firm.

In this Paper, we have two main objectives. First, given the competing theories and mixed empirical evidence in the literature about how investors behave around reputation-damaging events, we aim to introduce and analyze empirical evidence drawn from the financial industry on whether and why stock recommendations and credit ratings could act as a reputational asset or reputational liability upon the unexpected arrival of bad news into financial markets. Second, we aim to enhance the prediction models of the reputational damage caused by operational risk announcements through including expert advice variables (i.e. stock recommendations and credit ratings) that reflect the prior beliefs/expectations of more informed investors ${ }^{3}$.

Our study contributes to the literature on reputational risk and expert advice in several ways. First, this is the first paper to empirically examine whether stock recommendations and credit ratings could serve as a reputational shield in a business context. Second, we update the literature on the determinants of reputational risk by adding a new dimension which is the most recent expert advice. Finally, this paper provides evidence based on a post-global financial crisis sample $(2010-2014)$ that is more recent than any other empirical study on the factors affecting the reputational risk triggered by operational risk announcements in the financial industry.

The rest of this paper is organized as follows. Section 2 reviews the relevant literature and develops our testable hypotheses. Section 3 introduces the research methodology, including sample selection, variables tested and empirical models. Section 4 presents and discusses our main empirical results. The

\footnotetext{
${ }^{3}$ It is well-established in the literature that equity and debt analysts get access to much private information through different channels among which are their connections with the firm's management. Hence, it is expected that analyst's stock recommendations and credit ratings would drive the trading behavior of other less informed investors, especially individual (household) investors and liquidity traders (See Sections 2.2.1. and 2.2.2. for a more detailed discussion of the relevant literature).
} 
results of further analysis and robustness checks are presented and discussed in Sections 5 and 6, respectively. Section 7 concludes the paper.

\section{LITERATURE REVIEW AND HYPOTHESIS DEVELOPMENT}

\subsection{Review of the Literature on Operational and Reputational Risks}

Financial firms are unavoidably subject to reputational risk ${ }^{4}$ as a result of operational risk event announcements ${ }^{5}$. The Basel Committee on Banking Supervision's (BCBS) definition of operational risk $^{6}$ (Basel Committee on Banking Supervision, 2006) and evidence provided by the literature (Chernobai, Jorion, \& Yu, 2011; Cummins et al., 2006; T. Wang \& Hsu, 2013) show that operational risk event announcements reveal serious problems in internal control systems, potential fraudulent or opportunistic behavior on the part of management and employees, and ultimately weak tone-at-the-top corporate governance mechanisms in financial firms. Additionally, previous research found consistent evidence of the adverse reputational effects of large operational risk event announcements in the financial industry, as reflected by a drop in the market values of loss firms by more than one-to-one for internal fraud and non-fraud internally-caused operational losses (Cummins et al., 2006; Fiordelisi, Soana, \& Schwizer, 2014; Gillet et al., 2010; Perry \& Fontnouvelle, 2005; Sturm, 2013b) ${ }^{7}$.

Plunus, Gillet, \& Huebner, 2012 documented an adverse impact of operational risk announcements on cumulative abnormal bond returns on both the first press-cutting date and firm recognition date. They interpreted their results as "pure" reputational damage since operational risk losses usually do not deplete shareholders' equity and therefore should not be directly relevant to the expected cash flows received by creditors. In agreement with Gillet et al.'s, 2010 and disagreement with Sturm's, 2013b results on stock returns, Plunus et al., 2012 found that debt markets react favorably to settlement announcements. Sturm, 2013a inspected the impact of operational risk announcements on CDS markets in European banks and found that CDS spreads increase only around settlement announcements and when the relative operational loss size is higher. He interpreted these results as indicating that some

\footnotetext{
${ }^{4}$ Basel Committee on Banking Supervision (Basel Committee on Banking Supervision, 2009, p.19) defines reputational risk as "... the risk arising from negative perception on the part of customers, counterparties, shareholders, investors or regulators that can adversely affect a bank's ability to maintain existing, or establish new, business relationships and continued access to sources of funding (eg through the interbank or securitisation markets). Reputational risk is multidimensional and reflects the perception of other market participants. Furthermore, it exists throughout the organisation and exposure to reputational risk is essentially a function of the adequacy of the bank's internal risk management processes, as well as the manner and efficiency with which management responds to external influences on bank-related transactions."

${ }^{5}$ We use the terms "operational risk event announcements" and "Operational risk announcements" to indicate the same thing which is the first press-cutting announcement on a certain operational risk event in the public media news.

${ }^{6}$ Basel Committee on Banking Supervision (Basel Committee on Banking Supervision, 2006, p.144) defines operational risk as "...the risk of loss resulting from inadequate or failed internal processes, people and systems or from external events. This definition includes legal risk, but excludes strategic and reputational risk."

${ }^{7}$ For example, suppose that the market value of a firm dropped as a result of an announcement of an operational risk event. Then, a drop in the market value of three-to-one means that the magnitude of the market value drop is three times the magnitude of the operational loss. Hence, only one-to-one drop in the loss firm's market value is to be considered a mechanical market reaction to the operational loss amount disclosed whereas any excess drop in the market value would be considered a reputational loss.
} 
characteristics and timings of operational risk announcements cause an increase in the bank's default risk. We also believe that Sturm's, 2013a results confirm the debt-based "pure" reputational damage caused by operational risk announcements previously documented in bond markets by Plunus et al., 2012.

\subsection{Hypothesis Development}

\subsubsection{Equity Analysts' Stock Recommendations}

Analysts' stock recommendations reflect the favorability which highly informed investors and experts, that is equity analysts, believe to be involved in trading a particular stock. Stock recommendations range in a descending order of favorability from "Strong Buy" to "Buy" to "Hold" to "Underperform" to "Sell. Obviously, the more favorable the stock recommendation, the more inclined the less informed equity investors and liquidity traders would be to invest in this particular stock, thus causing the stock price to appreciate.

Chang \& Chan, 2008 found that the negative reaction of equity markets to downward stock recommendations is more than double the positive reaction to upward stock recommendations. Menéndez-Requejo, 2005 documented a positive (negative) equity market reaction to "Buy" ("Sell”) stock recommendations in a Spanish business context. Several other studies similarly confirmed the positive (negative) impact of "Buy" (“Sell”) stock recommendations on stock prices (Beneish, 1991; Davies \& Canes, 1978; Desai, Liang, \& Singh, 2000; Ferreira \& Smith, 2003; Liu et al., 1990). Wormac, 1996 found strong and persistent equity market reactions to extreme changes in stock recommendations (i.e. stocks added to or removed from "Buy" and "Sell" recommendations) over a one-to-six-month period following the recommendation changes. Barber \& Loeffler, 1993 documented the positive equity-based informational impact of stock recommendations published in the Wall Street Journal's monthly 'Dartboard' column. However, Barber, Lehavy, \& Trueman, 1999 found that equity investors would not incrementally benefit from stock recommendations made by top-ranked analysts. In addition, Barber et al., 2001 also found that a stock-recommendation-driven investment strategy would not necessarily be profitable, especially after controlling for transaction costs. Moreover, Desai \& Jain, 1995 found that money managers do not provide informative stock recommendations in relation to longterm stock performance.

These results reported in the stock recommendation literature are obviously mixed and call for further research to examine the differential effects of stock recommendations on equity markets under various market conditions. In this paper, we choose to investigate the impact of stock recommendations on the subsequent reputational damage to stock prices around operational risk announcements. We are interested in finding whether favorable stock recommendations would actually mitigate or accentuate the reputational damage which the financial firm could incur around operational risk announcements. 
We find it important to examine this reputational effect of stock recommendations from two perspectives. First, from the equity investor's perspective, our findings would guide their investment strategy and let them more accurately predict the equity market over-reactions or under-reactions associated with specific stock recommendations around operational risk announcements. Second, from the loss firm's perspective, our findings would advise their post-announcement reputation repair strategy and whether favorable stock recommendations could be sufficient as a protection shield against any reputational damage caused by operational risk announcements.

Previous research showed that prior good reputation could serve as either a reputational asset/protection or reputational liability/burden around reputation damaging events (Gatzert, 2015; Rhee \& Haunschild, 2006). From one side, a good reputation, that is backed up by well-established, legitimate and institutionalized expert advice, could make investors more confident in the ability of the affected firm to overcome the consequences of the loss event and repair its causes, thus triggering less adverse reactions from investors; we call this interpretation the "Institutional Legitimacy" theory (Minor \& Morgan, 2011; Pfarrer, Pollock, \& Rindova, 2010; Rhee \& Haunschild, 2006; Schnietz \& Epstein, 2005). From the other side, a good reputation (i.e. more favorable expert advice) could become a liability of the firm because prior optimistic investors' expectations have not been met, thus provoking investors to more aggressively penalize highly reputable firms following reputation damaging events; this is called the "Expectancy Violation Theory" (Rhee \& Haunschild, 2006; Wade, Porac, Pollock, \& Graffin, 2006).

In the case of operational risk announcements in financial institutions, the "Expectancy Violation Theory" interpretation might prevail for two reasons. First, financial institutions are known to have high information asymmetry due to complex business models, heavy regulation and supervision schemes and severe conflicts of interest among shareholders, managers, creditors and public interests (Srivastav \& Hagendorff, 2016). Such an information opacity would suggest that the financial industry is more likely to have the interrelationships of market risk (as partially implied by stock recommendations), credit risk (as partially implied by credit ratings) and operational risk (whose data is usually confidential and unavailable to the public) mispriced. Hence, operational risk announcements are more likely to inject new private information, thus reducing extant information asymmetry levels (Barakat, Chernobai, \& Wahrenburg, 2014) and correcting previous mispricing in the equity and debt markets. Second, the empirical evidence in the reputational risk literature documents that larger and more profitable financial firms with higher credit ratings are exposed to a more severe reputational damage (Fiordelisi, Soana, \& Schwizer, 2013; Sturm, 2013a).

Hence, upon the unexpected arrival of news, less informed equity investors and liquidity traders (i.e. naïve investors) would be inclined to revise their prior beliefs formed by the most recent stock recommendations. If those unexpected pieces of news reveal adverse information about the affected firm, as it is the case for operational risk announcements in financial institutions, naïve investors could 
then aggressively correct their prior optimistic beliefs and more heavily sell stocks with ex ante favorable stock recommendations. In this sense, the reputational damage caused by operational risk announcements could be an ex post correction of equity markets due to a strong revision of ex ante investors' expectations.

Additionally, since "Buy" stocks represent the most favorable stock recommendation in our sample, a big adverse correction of prior optimistic beliefs of equity investors around operational risk announcements could be expected for such stocks. Moreover, since "Hold" stocks imply the most longterm investment recommendation, this type of stock could be expected to incur the least severe equitybased reputational damage around operational risk announcements because the typical investor, seeking abnormal long-term returns, would simply continue to hold such stocks.

Furthermore, less heterogeneity in stock recommendations reflects lower market risk for investors and higher cross-sectional stock returns (Baik \& Park, 2003; Harrison \& Kreps, 1978). Hence, the unexpected arrival of bad news in the form of operational risk announcements would constitute a bigger surprise for firms with less dispersed stock recommendations, thus likely causing a more severe reputational damage.

However, according to the "Institutional Legitimacy" theory, it is plausible to theoretically argue that more favorable and less heterogeneous stock recommendations could serve as a reputationprotection vehicle whereby investors believe that such firms have forthcoming stronger performance and wealthier pool of economic resources that enable them to more efficiently absorb the adverse consequences of the announced operational risk events and more effectively remedy their fundamental causes. Hence, more optimistic and less dispersed expert opinion could help protect rather than damage the firm's reputation upon the unexpected arrival of bad news.

Therefore, given the competing theories and mixed empirical evidence in the literature, we formulate our first hypothesis as follows:

$H_{l}$ : There are reputational effects of stock recommendations around operational risk announcements in financial institutions

\subsubsection{Debt Analysts' Credit Ratings}

Analysts' credit ratings indicate the creditworthiness of the rated firm (i.e. its ability to honor the cash flow obligations of its liabilities; especially the repayments of interests and principals of its bond issuances) as evaluated by highly informed experts, that is credit rating agencies. The credit ratings generally range from "Prime" (AAA) to "In Default" (D) ${ }^{8}$. Obviously, the higher the credit rating level, the more inclined the less informed debt investors and liquidity traders would be to invest in the

\footnotetext{
${ }^{8}$ The credit rating levels used in this paper are based on the classifications of Standard \& Poor's (S\&P) long-term ratings.
} 
respective firm's bonds, thus increasing the market valuation of those bonds. Moreover, credit ratings are generally split into two major groups from the debt investor's perspective; Investment Grade "IG" and Speculative (Non-investment) Grade "SG". Speculative Grade firms/bonds are rated BB+ or lower and are sometimes termed "Junk Bonds"; they generally imply a much higher default risk than Investment Grade firms/bonds. Therefore, debt investors require a much higher return (i.e. due to a higher default risk premium) on their junk investments.

The impact of credit rating announcements on equity markets is quite controversial due to the known conflicts of interest between creditors and shareholders. For instance, Maxwell \& Stephens, 2003 found that credit ratings are more likely to be downgraded following open market share repurchases which increase the shareholders' wealth to the detriment of creditors' investments. Therefore, we include credit ratings as a control variable in our regressions modelling the equity-based reputational impact of operational risk announcements (although we are still interested in analyzing any inferences that can be drawn from their respective coefficients estimated in our multivariate equity-based regressions).

However, the impact of credit rating announcements on the CDS markets is more straightforward. In a recent study, Wang et al., 2014 studied the informational contents of credit rating updates in the Australian CDS market and found that credit rating updates have a slight negative impact on abnormal CDS spreads (i.e. positive impact on the implied default risk) and that outlook updates impose no significant effect on CDS markets. We add to the findings of Wang et al., 2014 by inspecting the reputational implications of credit rating levels around reputation-damaging operational risk announcements in financial institutions. We argue that our findings would benefit both the debt investors and the loss firm itself. For the debt investors, our findings provide evidence regarding the impact of credit rating levels on the implied default risk, thus enhancing the quality of the debt investor's investment decision around operational risk announcements. Second, our findings help the loss firm's management evaluate the extent to which their current credit rating level might serve as a reputationprotection mechanism around operational risk announcements and whether they would need further post-announcement actions to restore their firm's reputation.

Previous research has found a positive association between the incidence of operational risk and credit risk in financial institutions (Chernobai et al., 2011). Hence, it could be posited that debt investors ex ante expect that firms with higher credit rating levels will incur more frequent and/or more severe operational risk events. Hence, the unexpected arrival of bad news in the form of operational risk announcements could violate the prior expectations of debt investors, thus causing a more serious debtbased reputational damage for firms with higher credit rating levels. In line with this proposition, Sturm, 2013a found that CDS markets react more adversely to operational risk announcements in firms with higher credit ratings. 
However, according to the "Institutional Legitimacy" theory, credit ratings could act as a reputational shield since debt investors might view firms with higher credit rating levels (e.g. "IG" firms) as financially stronger and economically more stable, thus making such firms less vulnerable to bankruptcy following the announcements of operational risk events. Hence, debt investors could give firms with legitimate, institutionalized and more favorable creditworthiness the benefit of the doubt and penalize them less harshly upon the unanticipated release of the bad news.

Therefore, given the competing theories and mixed empirical evidence in the literature, we formulate our second hypothesis as follows:

$\mathrm{H}_{2}$ : There are reputational effects of credit ratings around operational risk announcements in financial institutions

\section{METHODOLOGY}

\subsection{Sample Selection and Composition}

The sample selection procedure is reported in Table 1. We begin with all 16,110 public announcements from the commercial ORIC International database which spans the period $1921-2015^{9}$. Since ORIC announcements were only regularly collected starting 2010, our sample period covers the post global financial crisis (post-GFC) years $(2010$ - 2014). We exclude announcements before 2010 and after 2014, announcements in non-financial firms (because the nature of operational risk is clearly different from that in financial institutions), announcements in loss firms not headquartered in USA, Europe, Canada, Australia, and Japan (to coincide with previous operational risk studies that mostly focused on advanced economies), announcements which have no clear operational risk classification (i.e. no event type or business line), announcements whose dates are not confirmed or full-text news articles not found (we have double-checked and downloaded available full-texts of operational risk announcements from LexisNexis news database) and announcements in privately held financial firms. To reduce noise in the data due to simultaneous market reactions to other types of announcements, we also exclude 98 operational risk announcements overlapping with earnings announcements or credit rating announcements (i.e. two trading weeks before and after the operational risk announcement). In addition, the only two announcements associated with "Underperform" stock recommendation are removed. Finally, 18 operational risk announcements are dropped due to missing data on variables collected from DataStream and Bloomberg.

\footnotetext{
9 ORIC International is a company that collects and reports both public and private operational loss data (www.oricinternational.com). In this paper, we use data from the public database, which consists of identified operational risk events around the world. Search algorithms are used to collect the data from the Internet. For this paper, the ORIC International data was extracted in March 2015.
} 
Hence, we end up with our final sample comprising 255 operational risk announcements from 81 financial institutions publicly listed in 20 countries which hit the public media news during the years 2010 - 2014 (Table 2, Panel A). Our final sample enables the generalization of our results as its size exceeds the sample sizes in most of previous studies on operational and reputational risks such as 115 events (1974 - 2004) in Perry and de Fontnouvelle (2005), 103 events (1994 - 2006) in Gillet et al. (2010), 71 events (1994 - 2006) in Plunus et al. (2012), 99 events (2004 - 2010) in Sturm (2013a) and 136 events (2000 - 2009) in Sturm (2013b); with the exception of 492 events (1978 - 2003) in Cummins et al. (2006) and 430 events (1994 - 2008) in Fiordelisi et al. (2014).

Our final sample is also well diversified as it encompasses 16 different industry subtypes of financial institutions (according to the Bloomberg classification) with most of the sample coming from bankingrelated activities (187/73\%) and the remaining events belonging to brokerage-related activities (19/8\%), wealth and investment management-related activities (34/13\%), and insurance-related activities $(15 / 6 \%)$ (Table 2, Panel B).

\section{[Insert Tables $1 \& 2$ here]}

\subsection{Variables Tested and Data Sources}

\subsubsection{Analysts' Stock Recommendations}

We collect data on the most recent consensus equity analysts' stock recommendations which are issued at least two trading weeks before each operational risk announcement from Bloomberg database. The data on consensus stock recommendations is collected and coded for our empirical analysis in a cardinal scale as follows: 1 for "Strong Buy", 2 for "Buy", 3 for "Hold", 4 for "Underperform" and 5 for "Sell". Obviously, favorability of the stock is decreasing in the cardinal scale used with the highest favorability for 1 and least favorability for 5. Our final sample comprises 108 "Buy" stocks and 147 "Hold" stocks (Table 2, Panel C).

We use the median stock recommendation to proxy for the central tendency of the most recent consensus stock recommendations. More specifically, we code a dummy variable Buy Stock Recommendation as 1 if the median of most recent consensus stock recommendations is "Buy" and 0 otherwise. To examine the impact of the heterogeneity of analysts' opinions regarding the favorability of the stocks, we employ the continuous variable StDev Stock Recommendation which is the standard deviation of the most recent consensus stock recommendations. 


\subsubsection{Credit Ratings}

Debt analysts' credit ratings reflect the credit risk involved in lending to a particular firm. Higher credit ratings obviously indicate a better creditworthiness of the borrowing firm. Credit ratings are subject to updates from time to time, when debt analysts find reasons to change their beliefs on the credit rating itself (i.e. upgrade or downgrade) or the intermediate-term outlook of the creditworthiness of the borrowing firm (i.e. positive, stable or negative). Since our sample includes no sufficient variation in the credit rating outlook data ${ }^{10}$, we focus our analysis on credit rating levels (i.e. "Prime" AAA to "In Default" D) and credit rating classifications (i.e. Investment Grade "IG" versus Speculative Grade "SG").

We collect data on the most recent Standard \& Poor's long-term, local issuer credit rating updates before each operational risk announcement from Bloomberg. Since the relationship between credit ratings and default risk is known to be non-linear, we convert our credit ratings into the corresponding default probability using the global corporate average cumulative default rate (five-year horizon) of S\&P long-term local issuer credit rating from 1981 to the year preceding the operational risk event announcement date. We use a five-year horizon because we are interested in the long-term reputational implications of operational risk announcements and to coincide with the five-year CDS spread data that is used to capture the debt-based reputational impact of operational risk announcements. Data on transition matrices is collected from the "Annual Global Corporate Default Study And Rating Transitions" reports published annually by S\&P Global and summarized in Appendix B. We name this variable Credit Rating Level.

Additionally, to capture the average equity-based and debt-based reputational differences across the two major credit rating groups from the debt investor's perspective, we construct a dummy variable Speculative Grade that is coded 1 if the most recent credit rating of the loss firm is BB+ or lower and 0 otherwise.

We were able collect credit rating data for 223 out of 255 announcements. The highest (lowest) credit rating level in our sample is AA (B-). In addition, $12 \%$ of our sample are Speculative Grade firms (Table 2, Panel D). As reported in Table 3, Credit Rating Level has an average (median) of 1.69\% $(0.69 \%)$ with a minimum (maximum) of $0.25 \%(28.76 \%)$.

\footnotetext{
${ }^{10}$ In our sample, 221 out of 223 most recent credit rating updates have a "Stable" outlook.
} 


\subsubsection{Equity-based Reputational Damage}

Following the literature on operational risk announcements (Fiordelisi et al., 2014, 2013; Gillet et al., 2010; Perry \& Fontnouvelle, 2005; Sturm, 2013b), we measure the direct equity market reaction to operational risk announcements using the cumulative abnormal stock return $(C A R)$ estimated by the single-index market model with the estimation period being a window of 250 trading days ending one calendar month before the announcement date. We use a more conservative approach reflected in a shorter event window $(-5,+5)$. We collect data on stock prices and local market indices from DataStream.

Also, following the literature on reputational risk (Fiordelisi et al., 2014, 2013; Gillet et al., 2010), we measure the equity-based reputational damage using the loss-adjusted $C A R$ (hereafter, Reputational Return or $R C A R$ ) which we compute according to the following formula:

$$
R C A R(-5,+5)=C A R(-5,+5)+\left|\frac{\text { Oprisk Loss Amount }(-5,+5)}{\text { Market Capitalization }(-6)}\right|
$$

We measure market capitalization six trading days before the announcement date to exclude any impact on the firm's market value caused by the leakage of private information in the trading week preceding the announcement date. We consider Oprisk Loss Amount $(-5,+5)$ to be zero when no operational loss amount is disclosed during the event window $(-5,+5)$. Since we use a relatively short event window $(-5,+5)$ which is clean from any other announcements, we believe that $R C A R(-5,+5)$ accurately measures the pure reputational impact (i.e. non-mechanical market reaction to the information disclosed in the operational risk announcement).

Table 3 shows that the mean $\operatorname{RCAR}(-5,+5)$ is $0.82 \%$ (p-value $=0.0608$ ) which indicates no reputational damage on average in our sample, thus contradicting previous papers on operational and reputational risks (Fiordelisi et al., 2014, 2013; Gillet et al., 2010) and hence gives a strong motivation to examine the factors which have caused this different result.

We estimate the following ordinary least squares (OLS) model to extract the equity-based reputational impact of analysts' stock recommendations around the announcement of an operational risk event $i$ incurred by the loss firm $j$ during the event window $(-5,+5)$ :

$$
\begin{aligned}
& \operatorname{RCAR}_{i j}(-5,+5) \\
&=\alpha_{i j}+\beta_{1} \text { Stock Recommendation }_{j}+\beta_{2} \text { Credit Rating }_{j} \\
&+\beta_{3} \text { Analyst Coverage }_{j}+\beta_{4} \text { Loss Disclosed Dum }_{i} \\
&+\beta_{5} \text { Firm Recognised Dum }_{i}+\beta_{6} \text { Regulatory Announced Dum }_{i} \\
&+\beta_{7} \text { Settlement Dum } \\
&+\beta_{8} \text { Different Country Dum }_{i}+\beta_{9} \text { Top Figures Dum }_{i} \\
&+\beta_{10} \text { Basel Business Line Dum }_{i}+\beta_{11} \text { Fraud Dum }_{i}+\beta_{12} \text { U. S. Firm Dum } \\
& \\
&+ \\
&+\beta_{13} \text { StDev Stock Return }_{j}+\beta_{14} \text { Beta }_{j}+\beta_{15} \text { Float }_{j}+\beta_{16} \text { Trading Volume }_{j} \\
&+\beta_{17} \text { Total Assets }_{j}+\beta_{18} \text { ROA }_{j}+\beta_{19} \text { Leverage }_{j}+\beta_{20} \text { Market to Book Ratio }_{j} \\
&+\beta_{21} \text { GDP Per Capita }_{j}+\epsilon_{i j}
\end{aligned}
$$


According to the particular version of the model estimated, Stock Recommendation ${ }_{j}$ could be either the median (i.e. Buy Stock Recommendation) or dispersion (i.e. StDev Stock Recommendation) of the most recent consensus stock recommendations preceding the operational risk event announcement. Similarly, dependent on the version of the model tested, Credit Rating ${ }_{j}$ could be either Credit Rating Level or Speculative Grade (as defined in Section 3.2.2.).

Since almost $48.60 \%$ of our sample announcements are associated with non-negative $R C A R(-5,+5)$ (i.e. supposedly not incurring an equity-based reputational damage) (Table 3 ), we devise a logit regression model to distinguish between firms incurring reputational damage and firms not incurring reputational damage around the operational risk announcement. In this sense, we look into how analysts' stock recommendations affect the likelihood of reputational damage. Our proposed logit model is more conservative than the order logit model used by Fiordelisi et al., 2013 who defined reputational damage as $R C A R$ in the lowest third of the RCAR distribution (even if it is non-negative).

We estimate the following binary logit model to estimate the impact of analysts' stock recommendations on the log-odds of equity-based reputational damage around the announcement of an operational risk event $i$ incurred by the loss firm $j$ during the event window $(-5,+5)$ :

$$
\begin{aligned}
& \ln \left(\frac{\operatorname{Pr}\left(R C A R_{i j}(-5,+5)<0\right)}{\operatorname{Pr}\left(R C A R_{i j}(-5,+5) \geq 0\right)}\right) \\
& =\eta_{i j}+\delta_{1} \text { Stock Recommendation }_{j}+\delta_{2} \text { Credit Rating }_{j} \\
& +\delta_{3} \text { Analyst Coverage }_{j}+\delta_{4} \text { Loss Disclosed Dum } \\
& +\delta_{5} \text { Firm Recognised Dum }_{i}+\delta_{6} \text { Regulatory Announced Dum } i \\
& +\delta_{7} \text { Settlement Dum }_{i}+\delta_{8} \text { Different Country Dum }_{i}+\delta_{9} \text { Top Figures Dum }_{i} \\
& +\delta_{10} \text { Basel Business Line Dum }{ }_{i}+\delta_{11} \text { Fraud Dum }_{i}+\delta_{12} \text { U.S.Firm Dum } \text { Dir }_{j} \\
& +\delta_{13} \text { StDev Stock Return }_{j}+\delta_{14} \text { Beta }_{j}+\delta_{15} \text { Float }_{j}+\delta_{16} \text { Trading Volume }_{j} \\
& +\delta_{17} \text { Total Assets }_{j}+\delta_{18} \text { ROA }_{j}+\delta_{19} \text { Leverage }_{j}+\delta_{20} \text { Market to Book Ratio }_{j} \\
& +\delta_{21} \text { GDP Per Capita } j+\mu_{i j}
\end{aligned}
$$

Heteroscedasticity-robust standard errors are used to infer the significance of regression coefficients produced by estimating our OLS and logit regression models. 


\subsubsection{Debt-based Reputational Damage}

Following (Sturm, 2013a), we employ the cumulative abnormal CDS spread change (CASC) and cumulative abnormal CDS relative spread change (CARSC) to measure the change in the implied default risk of the loss firm caused by operational risk announcements. To the extent that operational losses are covered by the shareholders' equity (i.e. only affect the expected cash flows received by the shareholders), operational risk events should not be relevant to the expected cash flows received by the creditors (Plunus et al., 2012). Hence, we argue that any positive impact on $C A(R) S C$ would indicate both an increase in the implied default risk of the loss firm and a pure reputational loss (i.e. debt-based reputational damage).

We have chosen to employ CDS spreads rather than bond returns to measure the debt-based impact of operational risk announcements (i.e. which we consider as a proxy for both the pure reputational impact and change in implied default risk around the operational risk announcement). There are three reasons for our choice. First, Ericsson, Jacobs, \& Oviedo, 2009 found that CDS spreads are superior to stock returns and bond returns in measuring the default risk of the business entity. Second, Mengle, 2007 documented a boost in CDS market liquidity due to the increased contribution of hedge funds in more recent years. Third, Blanco et al., 2005 showed that the causality relationship flows from CDS spreads (the cause) to bond spreads (the effect) and not vice versa.

Following Sturm, 2013a, we collect data on five year modified modified structure CDS spreads in Euros from DataStream and data on iTraxx index from Bloomberg.

We compute cumulative abnormal CDS spread change (CASC) as follows:

$$
\begin{gathered}
A S C_{i t}=\left(C D S_{i t}-C D S_{i t-1}\right)-\left(i \operatorname{Traxx}_{t}-i \operatorname{Traxx}_{t-1}\right) \\
\operatorname{CASC}_{(\boldsymbol{t \mathbf { 1 } , \boldsymbol { t } \mathbf { 2 } )}}=\sum_{\boldsymbol{t}=\boldsymbol{t}_{\mathbf{1}}}^{\boldsymbol{t}_{2}} A S C_{t}
\end{gathered}
$$

Also, we compute cumulative abnormal CDS spread relative change (CARSC) as follows:

$$
\begin{gathered}
\operatorname{ARSC}_{i t}=\left(\frac{\left(\operatorname{CDS}_{i t}-C D S_{i t-1}\right)}{C D S_{i t-1}}\right)-\left(\frac{\left(i \operatorname{Traxx}_{t}-i \operatorname{Traxx}_{t-1}\right)}{i \operatorname{Traxx}_{t-1}}\right) \\
\operatorname{CARSC}_{(\mathrm{t1,t2)}}=\sum_{t=\boldsymbol{t}_{\mathbf{1}}}^{\boldsymbol{t}_{2}} \operatorname{ASRC}_{t}
\end{gathered}
$$

Table 3 shows that the mean $\operatorname{CASC}(-5,+5)$ is 5.58 basis point $(\mathrm{p}$-value $=0.0001)$ and mean $\operatorname{CARSC}(-5,+5)$ is $2.13 \%$ (p-value $=0.0031$ ). This initial result shows that our sample announcements cause a severe debt-based reputational damage in CDS markets, thus calling for further research to examine the determinants of such a damage. 
Since operational risk announcements are known to directly hit the stock prices of loss firms but are only indirectly related to debt markets, we expect $\operatorname{RCAR}(-5,+5)$ to be an endogenous variable in the structural equation estimating the CDS market reactions to operational risk announcements. Differently speaking, we propose that the following instrumental variables: the equity analysts' stock recommendation (Buy Stock Recommendation), annualized standard deviation of daily stock returns (StDev Stock Return), systematic risk (beta), percentage of outstanding shares available to ordinary shareholders (float percent), and natural logarithm of trading volume (Trading Volume) to affect $C A(R) S C(-5,+5)$ only through their impact on $\operatorname{RCAR}(-5,+5)$.

Hence, to examine the debt-based reputational impact of credit ratings around the announcement of an operational risk event $i$ incurred by the loss firm $j$ during the event window $(-5,+5)$, we estimate the following two-stage least squares (2SLS) model:

First-stage Regression is to estimate the endogenous variable $R C A R(-5,+5)$ :

$$
\begin{aligned}
& \operatorname{RCAR}_{i j}(-5,+5) \\
&=\alpha_{i j}+\beta_{1} \text { Stock Recommendation }_{j}+\beta_{2} \text { Credit Rating }_{j} \\
&+\beta_{3} \text { Analyst Coverage }_{j}+\beta_{4} \text { Loss Disclosed Dum }_{i} \\
&+\beta_{5} \text { Firm Recognised Dum }_{i}+\beta_{6} \text { Regulatory Announced Dum }_{i} \\
&+\beta_{7} \text { Settlement Dum }_{i}+\beta_{8} \text { Different Country Dum }_{i}+\beta_{9} \text { Top Figures Dum }_{i} \\
&+\beta_{10} \text { Basel Business Line Dum }_{i}+\beta_{11} \text { Fraud Dum }_{i}+\beta_{12} \text { U. S. Firm Dum } \\
& \\
&+ \\
&+\beta_{13} \text { StDev Stock Return }_{j}+\beta_{14} \text { Beta }_{j}+\beta_{15} \text { Float }_{j}+\beta_{16} \text { Trading Volume }_{j} \\
&+\beta_{17} \text { Total Assets }_{j}+\beta_{18} \text { ROA }_{j}+\beta_{19} \text { Leverage }_{j}+\beta_{20} \text { Market to Book Ratio }_{j} \\
&+\beta_{21} \text { GDP Per Capita }_{j}+\epsilon_{i j}
\end{aligned}
$$

Second-stage regression is to estimate $C A(R) S C(-5,+5)$ :

$$
\begin{aligned}
& C A(R) S C_{i j}(-5,+5) \\
& =\kappa_{i j}+\gamma_{1} \text { Credit Rating }_{j}+\gamma_{2} \text { Analyst Coverage }_{j}+\gamma_{3} \text { Loss Disclosed Dum }_{i} \\
& +\gamma_{4} \text { Firm Recognised Dum }{ }_{i}+\gamma_{5} \text { Regulatory Announced Dum }{ }_{i} \\
& +\gamma_{6} \text { Settlement Dum }{ }_{i}+\gamma_{7} \text { Different Country Dum }{ }_{i}+\gamma_{8} \text { Top Figures Dum }_{i} \\
& +\gamma_{9} \text { Basel Business Line Dum }{ }_{i}+\gamma_{10} \text { Fraud Dum }_{i}+\gamma_{11} \text { U.S.Firm Dum } \text { Dir }_{j} \\
& +\gamma_{12} \text { Total Assets }_{j}+\gamma_{13} \text { ROA }_{j}+\gamma_{14} \text { Leverage }_{j}+\gamma_{15} \text { Market to Book Ratio }_{j} \\
& +\gamma_{16} \text { GDP Per Capita }{ }_{j}+\gamma_{17} R C A \widehat{R_{l \jmath}(}(-5,+5)+v_{i j}
\end{aligned}
$$

Where $R C A R_{l \jmath}(-5,+5)$ is the estimated value of $\operatorname{RCAR}(-5,+5)$ from the first-stage regression. Heteroscedasticity-robust standards errors are used to infer the significance of regression coefficients produced by estimating both stages of our 2SLS regression model. 


\subsubsection{Control Variables}

To properly identify our multivariate regression models, we include control variables that are commonly used in the market-based literature. To consider the information environment of the loss firm, we employ the number of analysts following the firm in the month preceding the announcement (Analyst Coverage). We collect data on analyst coverage from Bloomberg. Table 3 shows that at least one analyst has to be following the loss firm prior to the operational risk announcement in order to be included in our final sample. In Table 3, the mean (median) number of analysts following is 22(23) which reflects the adequate visibility that our sample firms enjoy, thus confirming the importance and relevance of expert advice to the equity and debt investors of these firms.

We also control for the size, profitability, leverage and growth of the loss firm using the natural logarithm of total assets (Total Assets), return on assets (ROA), long-term debt to shareholders' equity ratio (Leverage) and ratio of market value of equity to its book value (Market to Book Ratio), respectively. In addition to the accounting-based proxies, we control for the market-based performance of the loss firm. First, we control for the riskiness of the loss firm using market-based measures which are the annualized standard deviation of daily stock returns (StDev Stock Return) and monthly betas (Beta). Second, we consider the share's floatation by including the percentage of outstanding shares available to ordinary shareholders one week before the announcement date (Float). Third, we control for the trading volume by including the natural logarithm of the number of shares traded for the stock (in thousands) one week before the announcement date (Trading Volume). We collect accounting and market data from DataStream. Since we conduct a multi-country analysis, we control for the GDP per capita whose data is collected from the World Bank's website (GDP Per Capita). Table 3 shows the wide range of values for the accounting-based, market-based and country-level variables, thus confirming the diversity of our final sample.

Since the reputational impact of operational risk announcements could also be caused by the features of the operational risk event or characteristics of the announcement per se, we control for these factors in our empirical analysis. We collect data on event and announcement dummies by double-checking the contents of operational risk announcements in LexisNexis. First, we employ a dummy variable to capture whether the operational loss amount is disclosed or leaked in the event window $(-5,+5)($ Loss Disclosed Dum). Table 3 shows that $69 \%$ of our sample announcements have the operational loss amount disclosed during the event window $(-5,+5)$. In addition, we control for whether the operational risk event has been recognized by the loss firm itself (Firm Recognized Dum). This does not necessarily mean that the loss firm has issued a press release, but this recognition could simply be mentioned in the first press-cutting (for example, a representative of the loss firm has made a short comment confirming the event but challenging the relevant fine imposed by a regulatory body or court of law). 
Moreover, we include a dummy variable to indicate whether a simultaneous regulatory announcement concerning the operational risk event has been made (Regulatory Announced Dum). Almost always, operational risk announcements come out on the same trading day of the relevant regulatory announcement. Furthermore, a dummy variable is included to indicate whether the first announcement includes a final settlement (Settlement Dum). $16 \%$ of our final sample are final settlement announcements (Table 3). Furthermore, we control for the location of the operational risk event itself (not the announcement) and whether it has taken place in a different country from the loss firm's incorporation country (Different Country Dum).

Additionally, we consider whether the operational risk event has involved top corporate figures (i.e. board directors or one of the five highest paid executive officers of the loss firm) (Top Figures Dum). Moreover, since ORIC International employs additional "non-Basel II" business lines such as life insurance, general insurance and insurance broking, we include a dummy variable to control for the "Basel II" business lines which are: corporate finance, trading and sales, retail banking, commercial banking, payment and settlement, agency services, asset management and retail brokerage (Basel Business Line Dum). Table 3 shows that the majority of our final sample (78\%) are events incurred in "Basel II" business lines. We also control for the fraudulent nature of the event by including a dummy variable to capture whether the operational risk event is classified as an internal fraud or external fraud (Fraud Dum). Table 3 shows that $13 \%$ of our final sample are either internal fraud or external fraud events. Finally, we control for the regional effects by adding a dummy variable for events incurred by U.S. firms (U.S. Firm Dum).

[Insert Table 3 here]

\section{EMPIRICAL RESULTS}

\subsection{Univariate Analysis}

\subsubsection{Equity-based Reputational Effects of Analysts' Stock Recommendations}

Table 4 (Panel A) reports the mean $\operatorname{RCAR}(-5,+5)$ and proportion of operational risk announcements causing an equity-based reputational damage (i.e. negative $R C A R(-5,+5)$ ) for the "Buy" versus "Hold" stock recommendations and "Low Dispersion" versus "High Dispersion" stock recommendations in our final sample.

"Buy" firms are clearly associated with much lower reputational return (i.e. the difference is $1.79 \%$ and significant at the $10 \%$ level) and higher probability of reputational damage (i.e. the difference is approximately $14 \%$ and significant at the $5 \%$ level) than "Hold" firms. Subject to the conventional caveats of univariate analysis, this result initially indicates that equity investors are calmer around operational risk events incurred by "Hold" firms. One possible explanation is the long-term investment 
strategies that are implied by "Hold" stock recommendation and are less sensitive to short-term idiosyncratic informational shocks.

In addition to mean comparisons across median stock recommendation groups, we split our final sample into two groups according to the dispersion of most recent consensus stock recommendations. "Low Dispersion" group includes firms whose standard deviation of stock recommendations is lower than or equal to our sample's median (i.e. 0.93), whilst "High Dispersion" group includes the remaining observations.

"Low Dispersion" firms are clearly associated with much lower reputational return (i.e. the difference is $1.79 \%$ and significant at the $5 \%$ level) and higher probability of reputational damage (i.e. the difference is approximately $15 \%$ and significant at the 5\% level) than "High Dispersion" firms.

Again, our preliminary results suggest that equity investors revise their prior beliefs more aggressively and adversely when there is less ex ante heterogeneity in analyst's stock recommendations. Differently speaking, the informational shock caused by operational risk announcements is amplified when it is less expected (i.e. when there is more agreement among analysts' stock recommendations).

Overall, considering the typical reservation of no controlling for unobserved heterogeneity in univariate analysis, the results in Table (4), Panel (A) lend support to the "Expectancy Violation" theory whereby more favorable and less heterogeneous stock recommendations constitute a reputational liability due to heightened expectations that are seriously challenged by the unexpected negative information about the loss firm released via operational risk announcements.

\subsubsection{Debt-based Reputational Effects of Credit Ratings}

Table 4 (Panel B) reports the mean $\operatorname{CASC}(-5,+5)$ and mean $\operatorname{CARSC}(-5,+5)$ around operational risk announcements for the "Low Credit Rating" versus "High Credit Rating" groups and "Speculative Grade" versus "Investment Grade" groups in our final sample.

The "Low Credit Rating" group includes firms whose five-year cumulate default probability is higher than or equal to our sample's median (i.e. 0.69\%), whilst the "High Credit Rating” group includes the remaining observations.

The results strongly imply that lower credit ratings are reputationally damaging around operational risk announcements. First, on average, "Low Credit Rating" firms incur a higher $\operatorname{CASC}(-5,+5)$ (i.e. the difference is 11 basis points and significant at the $1 \%$ level) and a higher $\operatorname{CARSC}(-5,+5)$ (i.e. the difference is $3.5 \%$ and significant at the $5 \%$ level) than "High Credit Rating" firms. Second, "SG" firms incur a higher $\operatorname{CASC}(-5,+5)$ (i.e. the difference is 40 basis points and significant at the $1 \%$ level) and a higher $\operatorname{CARSC}(-5,+5)$ (i.e. the difference is $11.6 \%$ and significant at the $1 \%$ level) than "IG" firms. 
Overall, the results in Table (4), Panel (B) strongly support the "Institutional Legitimacy" theory whereby higher credit ratings serve as a reputational asset that could make investors grant the loss firm the benefit of the doubt and hence penalize it less harshly, thus ultimately alleviating the debt-based reputational damage caused by operational risk announcements.

\section{[Insert Table 4 here]}

\subsection{Multivariate Analysis}

\subsubsection{Equity-based Reputational Effects of Analysts' Stock Recommendations around Operational Risk Announcements}

Table 5 reports the effects of analysts' stock recommendations and most recent credit ratings on the reputational cumulative abnormal return $\operatorname{RCAR}(-5,+5)$ and the log-odds of equity-based reputational damage $\ln \left(\frac{\operatorname{Pr}\left(R C A R_{i j}(-5,+5)<0\right)}{\operatorname{Pr}\left(R C A R_{i j}(-5,+5) \geq 0\right)}\right)$ around operational risk event announcements incurred by financial institutions. Model (1) shows that firms with "Buy" stock recommendation incur a more severe reputational damage than firms with "Hold" stock recommendation. The adverse reputational impact is statistically significant and economically strong; "Buy" firms lose around $2 \%$ in reputational return more than "Hold" firms. In the same Model (1), there is no significant impact of the number of analysts following the firm Analyst Coverage on $\operatorname{RCAR}(-5,+5)$. This result implies that it is the favorability of analysts' recommendations, rather than the intensity of analyst coverage per se, that drives the equitybased reputational impact of unexpected bad news. In addition, Model (2) confirms the results in Model (1) by showing that "Buy" firms are more likely to incur an equity-based reputational damage (i.e. negative $\operatorname{RCAR}(-5,+5))$ around operational risk announcements.

It is interesting to note that once Credit Rating Level and Speculative Grade enter Models (3) and (5), respectively, the impact of Buy Stock Recommendation on $R C A R(-5,+5)$ becomes much weaker and insignificant. Nevertheless, even after controlling for the credit rating effects in Models (4) and (6), "Buy" firms are still more likely than "Hold" firms to suffer an equity-based reputational damage around operational risk announcements. Taken together, the results of Buy Stock Recommendation in Table (5) indicate that equity investors would revise their ex ante beliefs more aggressively for "Buy" firms than for "Hold" firms around operational risk announcements, thus increasing the likelihood of reputational damage for the earlier. However, considering the credit rating effects (which will be discussed later in this subsection), the extent of reputational damage for "Buy" firms might not be as severe as implied by the univariate results reported in Table (4), Panel (A). Overall, these results suggest that favorable stock recommendations constitute a reputational liability (i.e. a more favorite stock recommendation is associated with a more severe reputational damage) whereby unexpected bad news cause investors to revise downwardly their prior elevated expectations that have proved hard to be met. 
Moreover, in Table (5), Panel (A), Credit Rating Level enters insignificant in Models (3) and (4). However, Speculative Grade enters negative but insignificant (coefficient of -0.031043) in Model (5) estimating $R C A R(-5,+5)$ and enters positive and significant at the 5\% level (coefficient of 1.800284 ) in Model (6) estimating the log-odds of equity-based reputational damage. Hence, this result indicates that "SG" firms are more likely than "IG" firms to incur an equity-based reputational damage, but such a reputational damage might not be severe enough to warrant a significantly negative coefficient on Speculative Grade in Model (5). Overall, these results reflect that credit ratings act as a reputational asset whereby investors give "IG" firms the benefit of the doubt and hence penalize them less aggressively than "SG" firms once unanticipated adverse news hits the equity markets.

It is however crucial to note that the equity-based reputational results in Table (5) imply that stock recommendations constitute a reputational liability, whilst credit ratings serve as a reputational asset around operational risk announcements. There could be a number of explanations for this finding. First, by nature, credit ratings have a longer future horizon and are less volatile and less heterogeneous than stock recommendations. Second, credit ratings are institutionally issued and updated by fewer agencies ${ }^{11}$, whilst stock recommendations are developed and revised by a bigger number of individual analysts $^{12}$ some of whom might have been following the respective firm for a very short time, lack sufficient industry-specific expertise, or miss access to costly private information. Third, in some countries, increased regulation of equity research could give credit rating agencies an informational advantage by accessing private information that is not freely available to equity analysts. For example, Regulation Fair Disclosure in the U.S., prohibiting the selective nonpublic disclosure to equity analysts but allowing it to credit rating agencies, was found to substantially increase the informational content of credit rating updates (Jorion, Liu, \& Shi, 2005). Taking the three reasons together, it could be viable to believe that credit ratings are more "institutionally legitimate" than stock recommendations. In other words, less informed investors and liquidity traders show credit ratings as providing more stable and consistent information than stock recommendations about the future economic performance and risk profile of the respective firm. Hence, the idiosyncratic informational shocks cause equity investors to revise their ex ante beliefs formed by stock recommendations more frequently and more aggressively than they do for credit ratings.

\footnotetext{
${ }^{11}$ It is noteworthy that our empirical analysis covers the post global financial crisis period (post-GFC) during and immediately after which several credit rating agencies were heavily criticized by practitioners and academics, and fined by regulators and supervisors for their practices regarding inaccurate and upwardly biased credit ratings of financial institutions and instruments (Griffin \& Tang, 2011, 2012). Therefore, it can be expected that post-GFC (i.e. during our sample period) credit rating agencies have become more careful in issuing and updating their rating decisions, especially for financial institutions and instruments that were at the core of the harsh criticism.

${ }^{12}$ We realize that most of equity analysts work for brokerage houses but it is also well-established in the literature that individual analyst's characteristics, such as future career concerns (Horton, Serafeim, \& Wu, 2017) and behavioral bias (Mokoaleli-Mokoteli, Taffler, \& Agarwal, 2009), might create an incremental bias in their stock recommendations and earnings forecasts.
} 
The results in Table (5), Panel (B) show that StDev Stock Recommendation has no clear reputational impact around operational risk announcements. This indicates that investors revise their prior beliefs based on the median, rather than the dispersion, of stock recommendations. However, the results for Credit Rating Level and Speculative Grade resemble those reported in Table (5), Panel (A).

[Insert Table 5 here]

\subsubsection{Debt-based Reputational Effects of Credit Ratings around Operational Risk} Announcements

Since equity markets and CDS markets could react simultaneously to operational risk announcements, we consider this possible endogeneity when identifying our multivariate models for the debt-based reputational damage around operational risk announcements. Our main assumption here is that equity markets would react faster than CDS markets to operational risk announcements. This is because operational risk events and related losses are expected to directly hit the equity capital of a loss firm, whereas they will only indirectly impact on the long-term creditworthiness of the loss firm. Therefore, we treat $\operatorname{RCAR}(-5,+5)$ as an endogenous variable in the models identifying the debt-based reputational effects of credit ratings around operational risk announcements.

Table 6 reports the results on the debt-based reputational effects of credit rating levels and "SG" ratings around operational risk announcements in financial institutions. Due to limited CDS data availability, the debt-based sample (135 observations) is obviously much smaller than the equity-based sample (255 observations), whose results are reported in Table 5. However, our debt-based sample is still bigger than the samples used in Sturm, 2013a and Plunus et al., 2012 who also studied the impact of operational risk announcements in debt (CDS and bonds) markets although they have covered longer sample periods in their respective studies.

Firstly, starting with Table 6 (panel A), the endogeneity (Stock-Write) test (i.e. test values range from 3.27 with p-value of 0.6578 in Model (2) estimating $C A S C(-5,+5)$ to 3.39 with p-value of 0.6404 in Model (3) estimating $\operatorname{CARSC}(-5,+5))$ fails to reject the null hypothesis that $R C A R(-5,+5)$ is an endogenous variable in the structural equation identified. Hence, after passing the endogeneity test, we move on to test the validity of the instrumental variables chosen. As discussed in Section 3.2.4., we have employed five instrumental variables which are the "Buy" stock recommendation (Buy Stock Recommendation), annualized standard deviation of daily stock returns (StDev Stock Return), systematic risk (beta), the percentage of outstanding shares available to ordinary shareholders (float percent), and the natural logarithm of the stock's trading volume (Trading Volume). The F-test of excluded instruments (i.e. test value is 2.60 and p-value is 0.029 ) rejects the null hypothesis that those instrumental variables can jointly be excluded from the first-stage regression (i.e. the regression estimating $\operatorname{RCAR}(-5,+5)$ ). Hence, we deduce that the instrumental variables employed are strictly exogenous to the second-stage regression. 
To confirm the validity of our group of instrumental variables, the overidentification (Sargan) test (i.e. test values range from 0.925 with p-value of $0.9209 \mathrm{in} \mathrm{Model} \mathrm{(2)} \mathrm{to} 1.910$ with p-value of 0.7524 in Model (3)) fails to reject the null hypothesis that the structural equation is not over-identified meaning that there are no redundant instruments. Regarding the strength of the instrumental variables selected (i.e. their joint explanation power of $\operatorname{RCAR}(-5,+5)$ ), the partial R-squared of excluded instruments is 0.0987 indicating that variations in our instrumental variables explain, on average, around $9.87 \%$ of variations in $R C A R(-5,+5)$ ). Although this is not a high $\mathrm{R}$-squared value, considering previous papers using 2SLS regression models (for example, Laeven \& Levine, 2009), it would still indicate that our chosen instruments are not weak.

Regarding the second-stage regression, the coefficients of Credit Rating Level enter statistically significant and economically powerful. For Model (2) estimating $\operatorname{CASC}(-5,+5)$, the coefficient of Credit Rating Level is 10.07 (p-value < 0.01). This is a big economic magnitude; for example, a credit rating downgrade from AA- to $\mathrm{A}+$ in 2014 (i.e. amounting to $0.14 \%$ increase in the five-year cumulative default probability; see Appendix B) would increase $\operatorname{CASC}(-5,+5)$ by 1.41 basis point. However, the economic impact would be much more severe if the downgrade is across lower credit ratings. For example, a credit rating downgrade from BB- to B+ in 2014 (i.e. amounting to $5.72 \%$ increase in the five-year cumulative default probability; see Appendix B) would increase $\operatorname{CASC}(-5,+5)$ by 57.60 basis point (approximately, 40 times bigger than the increase in $\operatorname{CASC}(-5,+5)$ following the AA- to A+ downgrade).

The results in Model (3) estimating $\operatorname{CARSC}(-5,+5)$ confirm the findings in Model (2). The coefficient of Credit Rating Level is 0.0367 (p-value < 0.01). Again, the economic magnitude is economically strong since a one-point downgrade from AA- to A+ and from BB- to B+ in 2014 would cause an increase in $\operatorname{CARSC}(-5,+5)$ by $0.51 \%$ and $21 \%$, respectively.

The results in Table (6), Panel (B) support the findings inferred from Table (6), Panel (A). In summary, "SG" firms incur a more severe debt-based reputational damage than "IG" firms around operational risk announcements. More specifically, on average, an "SG" firm would incur $\operatorname{CASC}(-5,+5)(\operatorname{CARSC}(-5,+5))$ that is higher by 41.08 basis point $(15.34 \%)$ than "IG" firms. These results are qualitatively similar to the mean differences reported in Table (4), Panel (B); again, confirming our inferences about the reputational shields created by higher credit ratings.

Taken together, the results in Table (6) imply two main findings. First, credit ratings serve as a reputational asset that effectively mitigates the adverse debt-based reputational consequences of operational risk announcements. Second, the debt-based reputational effects of credit ratings around operational risk announcements are non-linear (i.e. a one-point credit rating downgrade could seriously be more damaging; both economically and reputationally, if it happens at the lower "SG" ratings).

[Insert Table 6 here] 


\section{FURTHER ANALYSIS}

\subsection{U.S. Firms}

Most of previous studies on the reputational effects of operational risk announcements have been performed in an international context (for example, Fiordelisi et al., 2013; Perry \& Fontnouvelle, 2005; Plunus et al., 2012)). In Addition, Gillet et al. (2010) have compared US and European subsamples and found that the reputational damage occurs only in US firms possibly due to their higher market values which lower the magnitude of the mechanical market reaction to the operational risk announcement (i.e. the operational loss amount divided by the loss firm's market value). On the contrary, Fiordelisi et al. (2014) found that the reputational losses are more severe in European firms. Given this mixed evidence in the literature, we want to find out whether our empirical results differ across regions. Hence, we interact U.S. Firm Dum with our four measures of expert advice ${ }^{13}$.

The results, reported in Table (7), Panel (A) $)^{14}$, show that all our empirical results are not different across regions, except for the standard deviation of stock recommendations; the variable of interest is the interaction term StDev * U.S. Firm. In Model (3) estimating RCAR $(-5,+5)$, StDev * U.S. Firm enters negative (-0.218457) and significant at the 5\% level. It indicates that more heterogeneity in analysts' stock recommendations would trigger a reputational damage only if the operational risk event is incurred by a U.S. firm. However, it is noteworthy that StDev Stock Recommendation has a significantly positive coefficient (0.127155). Moreover, the results reported in Model (4) estimating the log-odds of equity-based reputational damage confirm the findings from Model (3).

Thus, adhering to the "Expectancy Violation" theory, less heterogeneous stock recommendations would constitute a reputational liability around operational risk announcements only in non-U.S. firms. One possible explanation for this finding is that, in our sample, StDev Stock Recommendation is, on average, significantly higher in non-U.S. firms (0.95) than U.S. firms (0.83); hence, equity investors would view stock recommendations of non-U.S. firms to be less stable (i.e. less legitimate) and more aggressively challenge them around sizable informational shocks.

\footnotetext{
${ }^{13}$ In unreported further analysis, we attempted other geographical regions and countries such as United Kingdom and Japan, but we did not find any significant differences for our four measures of expert advice.

${ }^{14}$ For the sake of brevity, only the variables of interest are reported in Tables 7 and 8.
} 


\subsection{Fraud Incidents}

$13 \%$ of our sample are fraud events (i.e. internal fraud or external fraud) ${ }^{15}$. Previous studies have documented strong adverse reputational consequences of fraud events in financial institutions. For example, Perry and Fontnouvelle (2005) documented a drop in the market value by more than double the operational loss ratio for internal fraud announcements. However, Fiordelisi et al. (2014) have found that external fraud announcements cause the most severe reputational damage. Other studies such as Sturm (2013b) and Fiordelisi et al. (2013) have not located a conclusive evidence regarding the reputational effects of operational risk event types. Given this mixed evidence in the literature, we are interested in examining how event types might be driving our empirical results. Hence, we interact Fraud Dum with our four measures of expert advice ${ }^{16}$.

The results, reported in Table (7), Panel (B), show that only our debt-based inferences are effected by fraud incidence. In Model (5) estimating $\operatorname{CASC}(-5,+5)$, the interaction term Credit Rating Level * Fraud enters positive and significant at the $5 \%$ level (the coefficient is 2.15). This result indicates that credit ratings play a more important role as a reputational shield when a fraud event is announced. For example, a one-point upgrade from B+ to BB- in 2014 (i.e. amounting to 5.72\% decrease in the fiveyear cumulative default probability; see Appendix B) would decrease $\operatorname{CASC}(-5,+5)$ by an increment of 12.3 basis point for fraud events. Model (7), also estimating $\operatorname{CASC}(-5,+5)$, confirm the inferences above; "SG" firms suffer an additional increase in $\operatorname{CASC}(-5,+5)$ amounting to 7.86 basis points for fraud events. However, the interaction terms Credit Rating Level * Fraud and Speculative Grade* Fraud enter economically powerful but statistically insignificant in Models (6) and (8) estimating $\operatorname{CARSC}(-5,+5)$.

Overall, we interpret these results as supporting the "Institutional Legitimacy" theory for credit ratings. Since fraud events usually raise more serious suspicions about the integrity of senior management and other employees of the loss firm (in the case of internal fraud) and the effectiveness of preventive and detective internal controls (in the case of external fraud), the "institutional" and "legitimate" credit ratings should be more instrumental in cooling down investors' frustrations and mitigating the debt-based reputational damage caused by operational risk announcements involving fraud allegations.

\footnotetext{
${ }^{15}$ There are six event types in our final sample whose counts are: Internal Fraud (13), External Fraud (19), Clients, Products and Business Practices (212), Execution, Delivery and Process Management (4), Employment Practices and Workplace Safety (4), Business Disruption and System Failures (3).

${ }^{16}$ In unreported further analysis, we examined the interaction effects of other event types such as Internal Fraud (separately), External Fraud(separately), Clients, Products, and Business Practices and Executive, Delivery, and Process Management, but we did not find any significant differences for our four measures of expert advice.
} 


\subsection{Basel Business Lines}

Few previous studies on operational risk have focused on business lines as classified by Basel II (BCBS, 2006). One possible reason is the absence of clear theory to distinguish between different business lines as this classification seems to be driven mainly by practical implications rather than theoretical justifications. In an international sample, Fiordelisi et al. (2014) have found that "Trading and Sales" and "Payment and Settlement" events incur the most severe reputational damage. To put more robust theoretical reasoning behind this bit of further analysis, we distinguish between the eight Basel business lines as one group (i.e. Basel Business Line Dum =1) and other non-Basel business lines used in ORIC (i.e. Basel Business Line Dum $=0)^{17}$. It is noteworthy that most non-Basel business lines (we call it ORIC business lines) are available in non-banking firms. Hence, Basel Business Line Dum mostly captures the bank-specific business models. ${ }^{18}$

The results, reported in Table (7), Panel (C), show that credit ratings are more crucial in protecting from the debt-based reputational damage incurred by operational risk announcements in non-Basel business lines (i.e. non-banking activities). In Model (5) estimating $\operatorname{CASC}(-5,+5)$, the interaction term Credit Rating Level * Basel enters negative (-2.27) and significant at the 5\% level. For example, a onepoint upgrade from B+ to BB- in 2014 (i.e. amounting to $5.72 \%$ decrease in the five-year cumulative default probability; see Appendix B) would decrease $\operatorname{CASC}(-5,+5)$ by an increment of 13 basis point for non-Basel business lines. Also, in Model (7) estimating $\operatorname{CARSC}(-5,+5)$, the interaction term Speculative Grade * Basel enters negative (-8.84) and significant at the 5\% level. This result indicates that, on average, transiting from the "SG" category to the "IG" category would decrease $\operatorname{CASC}(-5,+5)$ by an increment of 8.84 basis point for non-Basel business lines. The results in Models (6) and (8) estimating $\operatorname{CARSC}(-5,+5)$ confirm the findings above.

One possible explanation for this result is that, compared with non-banks (i.e. non-Basel business lines), there is more regulated operational risk management and disclosure (e.g. robust methods of quantifying and reporting the operational risk regulatory capital) and stronger investor protection (e.g. deposit guarantees) in banks (i.e. Basel business lines), thus downplaying the importance of credit ratings as soft reputational shields.

\footnotetext{
17 There are fourteen business lines in our final sample whose counts are: Agency Services (13), Asset Management (5), Commercial Banking (14), Corporate Finance (14), Corporate Services (32), Financial Exchanges (3), General Insurance (4), Insurance Broking (4), Life Assurance (5), Payments and Settlement (6), Wealth Management (7), Retail Banking (77), Retail Brokerage (10), Trading and Sales (61).

${ }^{18}$ In unreported further analysis, we substitute Basel Business Line Dum with another dummy variable that equals 1 if the loss firm is a bank and 0 otherwise. The results remain qualitatively similar; thus, confirming our conjecture about the differences between Basel business lines and ORIC business lines.
} 


\subsection{Top Figures}

Several studies have documented a firm-level and manager-level reputational damage following adverse news announcements such as fraud allegations and financial statement restatements involving senior management (for example, Chakravarthy, De Haan, \& Rajgopal, 2014; Desai, Hogan, \& Wilkins, 2006; Fich \& Shivdasani, 2007). Hence, we want to find out whether our empirical results are sensitive to operational risk announcements including top figures in the loss firm. By top figures we mean any board director or one of the five highest paid executives affiliated with the loss firm at the time of the announcement. The announcement needs to explicitly mention that the top figure is directly responsible for the operational risk event. Applying these criteria, only $8 \%$ of our sample events are associated with a top figure.

Our results, reported in Table (7), Panel (D), indicate that equity investors revise their prior beliefs more aggressively for less heterogeneous stock recommendations when the bad news involves a top figure. The consequences could be disastrous to the loss firm since, according to Model (3) estimating $R C A R(-5,+5)$, a one-point decrease in StDev Stock Recommendation (i.e. less heterogeneity) would cause $\operatorname{RCAR}(-5,+5)$ to drop by an increment of $41.5 \%$ when the operational risk event is committed by a top figure. The results in Model (4) estimating the log-odds of equity-based reputational damage confirm the findings above.

Collectively, this result implies that announcing a misconduct of senior management in less risky firms (i.e. where analysts disagree less about its stock recommendation) causes an extremely serious downward correction of investors' ex ante expectations about the firm's future economic profile; thus, demolishing its reputation and, possibly, raising a going-concern red flag. ${ }^{19}$

[Insert Table 7 here]

\section{ROBUSTNESS CHECKS}

\subsection{Settlement Loss Amount as a Correction for All Events}

As explained in Section 3.2.3., to compute $\operatorname{RCAR}(-5,+5)$, we utilized the ratio of the actual disclosed loss amount to the loss firm's market value in order to partial out the mechanical market reaction included in $C A R(-5,+5)$. Two reservations can be made about using the actual disclosed loss amount. First, the loss amount to market value adjustment would be forced to be zero in all announcements where the loss amount is unknown at the announcement date; hence, possibly, downwardly biasing our equity-based reputational measure $\operatorname{RCAR}(-5,+5)$. Second, according to Gillet et al. (2010), market participants can unbiasedly estimate the future loss amount. Hence, as a

\footnotetext{
${ }^{19}$ In unreported further analysis, we interacted our four measures of expert advice with other event and announcement characteristics which are: Loss Disclosed Dum, Firm Recognized Dum, Regulatory Announced Dum, Settlement Dum, and Different Country Dum, but we could not find significant or consistent results for the interaction terms.
} 
robustness check, we use the ex post (settlement) loss amount as a correction for all events in our final sample..$^{20}$

The results reported in Table (8), Panel (A) are rerun replications of the regressions in Tables (5) and (6) using the alternative measure of $\operatorname{RCAR}(-5,+5)$. For the sake of brevity, only the coefficients of our four measures of expert advice are reported. Clearly, the results in all eight models strongly coincide with the findings in our main regressions; thus, confirming that the inferences drawn are not affected by any possible bias in our equity-based reputational measure. ${ }^{21}$

\subsection{Time Elapsed Since Last Credit Rating Update}

Another reservation that can be made about our results is that there could be a considerable lag period between the operational risk event and preceding credit rating update; thus, possibly diluting any reputational effects of credit ratings due to new information injected into the markets during this lag period. Hence, as a robustness check, we introduce the variable Lag which is the number of days since the most recent credit rating update ${ }^{22}$. The variables of interest are Credit Rating Level $*$ Lag and Speculative Grade * Lag.

The results, reported in Table (8), Panel (B), show that the equity-based reputational effects of credit ratings weaken as more time elapses. In Model (1) estimating $\operatorname{RCAR}(-5,+5)$, Credit Rating Level enters negative (-0.009077) and significant at the 1\% level, whilst the interaction term Credit Rating Level * Lag enters positive (0.000012) and significant at the 5\% level. This result implies the contribution of credit ratings as an equity-based reputational shield deteriorates by time and that credit ratings, in the long term, become an equity-based reputational liability. In other words, the more time is elapsed since most recent credit rating, the more aggressively equity investors would revise their prior beliefs around operational risk announcements in firms with higher credit ratings. The results in Models (2), (3), and (4) confirm the findings above for the log-odds of equity-based reputational damage and "IG" firms. Our results coincide with Wade et al. (2006) who found that CEO certifications gained from Financial World's contest cause short-term positive abnormal returns but impose a long-term adverse impact on the firm's market performance.

To clarify the economic magnitude and implication of this result, we give the following example. The turnaround point (i.e. the point of time at which credit ratings become a reputational liability rather than a reputational asset), suggested my Model (1), is 756 days which correspond to approximately $66 \%$

\footnotetext{
${ }^{20}$ The average (median) settlement loss is USD 301 (73) million and its minimum (maximum) is USD $1.19(6,108)$ million. Its standard deviation is USD 686 million.

${ }^{21}$ In unreported robustness checks, we reran all our main regressions for different shorter event windows such as $(-1,+1),(-$ $3,+3),(0,+3),(0,+5)$ and found qualitatively similar results though little weaker for very short event windows such $(-1,+1)$ and post-event windows such as $(0,+3)$. This implies that the reputational effects of expert advice need longer time to materialize and extend to influence investors' behaviour in the pre-event windows when private and uncertain information about the operational risk event might have leaked into the markets.

${ }^{22}$ The average (median) Lag is 525 (639) days and its minimum (maximum) is 38 (2088) days. Its standard deviation is 425 days.
} 
of our sample. Now, let us assume that two identical operational risk events are incurred by two firms, (A) and (B), on the same day in 2014. Both firms have the same credit rating BBB+; however, the only difference is that the lag since most recent credit rating is 100 days for firm (A) and 900 days for firm (B). Hence, according to Model (1), if both firms were rated one-point higher (for example, A- rather than $\mathrm{BBB}+$; corresponding to a reduction of $0.58 \%$ in the five-year cumulative default probability; see Appendix (B)), this would increase $\operatorname{RCAR}(-5,+5)$ by $0.46 \%$ in firm (A), but decrease it by $0.10 \%$ in firm (B). Hence, higher credit ratings would serve as an equity-based reputational asset in firm (A) and an equity-based reputational liability in firm (B).

It is however noteworthy that, unlike the equity-based results discussed above, the time elapsed does not dilute the debt-based reputational effects of credit ratings. In Models (5), (6), (7), and (8), both interaction terms Credit Rating Level * Lag and Speculative Grade * Lag enter insignificant. This indicates that, regardless of the lag, higher credit ratings would persistently serve as a debt-based reputational shield around operational risk announcements. One possible explanation for the differences between the equity-based and debt-based reputational results is that equity-based investors of publicly listed firms are protected from the corporate bankruptcy consequences by the "Shareholder's Limited Liability" harbor and therefore tend to revise the reputational implications of credit ratings over time. On the contrary, debt investors view credit ratings as a direct measure of the firm's default risk and an indirect measure of its reputation and therefore are less likely to revise their prior beliefs only because of elapsed time.

\section{[Insert Table 8 here]}

\section{CONCLUSIONS}

Based on a sample of 255 operational risk event announcements from 81 financial institutions publicly listed in 20 countries which hit the public media news during the post-global financial crisis years 2010 - 2014, our empirical results strongly support the proposition that stock recommendations and credit ratings drive the reputational effects caused by the unexpected arrival of bad news into financial markets. However, the persistence and magnitude of such reputational effects differ according to several factors.

Generally speaking, stock recommendations represent a reputational liability, whilst credit ratings serve as a reputational asset around operational risk announcements in financial institutions. More specifically, "Buy" stocks and "SG" firms are more likely to incur an equity-based reputational damage. Moreover, firms with lower credit ratings incur a much more severe debt-based reputational damage.

Additionally, we performed a further analysis to find out whether the reputational effects of expert advice are moderated by event characteristics. A number of interesting inferences are drawn. First, equity investors revise their prior beliefs more aggressively in non-US firms with less heterogeneous stock recommendations. Second, credit ratings are more instrumental in mitigating the debt-based 
reputational damage caused by fraud incidents or incurred in non-Basel business lines (i.e. non-banking activities). Third, the misconduct of senior management could demolish the reputation of firms with less heterogeneous stock recommendations.

Finally, our robustness checks reveal two additional findings. First, our main empirical results are robust to the usage of settlement loss as a correction in computing our equity-based reputational measure. Second, credit ratings serve as an equity-based reputational asset in the short term but turn into a reputational liability in the long term.

All in all, our paper covers the most common source of reputational risk in the financial industry; that is operational risk announcements. However, further research could be done to examine the reputational effects of expert advice for other reputation damaging events in financial and non-financial firms, such as money laundry cases, product recalls, downsizings and layoffs. Moreover, future studies could investigate whether credit-related operational risk event announcements might cause a debt-based reputational damage which is more severe than the resulting equity-based reputational damage. 


\section{REFERENCES}

Baik, B., \& Park, C. (2003). Dispersion of analysts' expectations and the cross-section of stock returns. Applied Financial Economics, 13(11), 829-839. https://doi.org/10.1080/0960310032000129617

Barakat, A., Chernobai, A., \& Wahrenburg, M. (2014). Information asymmetry around operational risk announcements. Journal of Banking and Finance, 48, 152-179.

Barber, B., Lehavy, R., McNichols, M., \& Trueman, B. (2001). Can Investors Profit from the Prophets? Security Analyst Recommendations and Stock Returns. The Journal of Finance, 56(2), 531-563. https://doi.org/10.1111/0022-1082.00336

Barber, B., Lehavy, R., \& Trueman, B. (1999). Brokerage Houses and their Stock Recommendations: Does Superior Performance Persist? UCLA Anderson School of Management. https://doi.org/10.2139/ssrn.181299

Barber, B., \& Loeffler, D. (1993). The "Dartboard" Column: Second-Hand Information and Price Pressure. The Journal of Financial and Quantitative Analysis, 28(2), 273-284.

Basel Committee on Banking Supervision. (2006). International Convergence of Capital Measurement and Capital Standards. Bank for International Settlements. Retrieved from http://www.bis.org/publ/bcbs128.pdf

Basel Committee on Banking Supervision. (2009). Proposed enhancements to the Basel II framework.

Beneish, M. (1991). Stock Prices and the Dissemination of Analysts â $€^{\mathrm{TM}}$ Recommendation. The Journal of Business, 64(3), 393-416.

Blanco, R., Brennan, S., \& Marsh, I. W. (2005). An Empirical Analysis of the Dynamic Relation between Investment-Grade Bonds and Credit Default Swaps. Journal of Finance, 60(5), 1-27. https://doi.org/10.1111/j.1540-6261.2005.00798.x

Boot, A. W. A., Milbourn, T. T., \& Schmeits, A. (2006). Credit ratings as coordination mechanisms. Review of Financial Studies. https://doi.org/10.1093/rfs/hhj009

Chakravarthy, J., De Haan, E., \& Rajgopal, S. (2014). Reputation repair after a serious restatement. Accounting Review, 89(4), 1329-1363. https://doi.org/10.2308/accr-50716

Chang, Y.-H., \& Chan, C.-C. (2008). Financial analysts' stock recommendation revisions and stock price changes. Applied Financial Economics, 18(1978), 309-325. https://doi.org/10.1080/09603100600606131

Chernobai, A., Jorion, P., \& Yu, F. (2011). The Determinants of Operational Risk in U.S. Financial Institutions. Journal of Financial and Quantitative Analysis, 46(6), 1683-1725. https://doi.org/10.1017/S0022109011000500 
Chung, K. H., Ann Frost, C., \& Kim, M. (2012). Characteristics and Information Value of Credit Watches. Financial Management, 4l(1), 119-158. https://doi.org/10.1111/j.1755053X.2012.01180.x

Creighton, A., Gower, L., \& Richards, A. J. (2007). The impact of rating changes in Australian financial markets. Pacific Basin Finance Journal, 15(1), 1-17. https://doi.org/10.1016/j.pacfin.2006.04.003

Cummins, J. D., Lewis, C. M., \& Wei, R. (2006). The market value impact of operational loss events for US banks and insurers. Journal of Banking and Finance, 30(10), 2605-2634. https://doi.org/10.1016/j.jbankfin.2005.09.015

Davies, P., \& Canes, M. (1978). Stock prices and the publication of second-hand information. The Journal of Business, 51(1), 43-56.

Desai, H., Hogan, C. E., \& Wilkins, M. S. (2006). The reputational penalty for aggressive accounting: Earnings restatements and management turnover. Accounting Review. https://doi.org/10.2308/accr.2006.81.1.83

Desai, H., \& Jain, P. C. (1995). An Analysis of the Recommendations of the "Superstar" Money Managers at Barron's Annual Roundtable. The Journal of Finance, 50(4), 1257-1273. https://doi.org/10.2307/2329351

Desai, H., Liang, B., \& Singh, A. K. (2000). Do All-Stars Shine? Evaluation of Analyst Recommendations. Financial Analysts Journal, 56(3), 20-29. https://doi.org/10.2469/faj.v56.n3.2357

Ericsson, J., Jacobs, K., \& Oviedo, R. (2009). The Determinants of Credit Default Swap Premia. Journal of Financial and Quantitative Analysis, 44(1), 109-132. https://doi.org/10.1017/S0022109009090061

Ferreira, E., \& Smith, S. (2003). "Wall Street Week": information or entertainment? Financial Analysts JournalJournal, 59(1), 45-53.

Fich, E. M., \& Shivdasani, A. (2007). Financial fraud, director reputation, and shareholder wealth. Journal of Financial Economics, 86(2), 306-336. https://doi.org/10.1016/j.jfineco.2006.05.012

Fiordelisi, F., Soana, M.-G., \& Schwizer, P. (2014). Reputational losses and operational risk in banking. European Journal of Finance, 20(2), 105-124. https://doi.org/10.1080/1351847X.2012.684218

Fiordelisi, F., Soana, M. G., \& Schwizer, P. (2013). The determinants of reputational risk in the banking sector. Journal of Banking and Finance, 37(5), 1359-1371. https://doi.org/10.1016/j.jbankfin.2012.04.021 
Gatzert, N. (2015). The impact of corporate reputation and reputation damaging events on financial performance: Empirical evidence from the literature. European Management Journal, 33(6), 485-499. https://doi.org/10.1016/j.emj.2015.10.001

Gillet, R., Hübner, G., \& Plunus, S. (2010). Operational risk and reputation in the financial industry. Journal of Banking and Finance, 34(1), 224-235. https://doi.org/10.1016/j.jbankfin.2009.07.020

Goh, J. C., \& Ederington, L. H. (1993). Is a Bond Rating Downgrade Bad News, Good News, or No News for Stockholders? Journal of Finance, 48(5), 2001-2008. https://doi.org/10.1111/j.15406261.1993.tb05139.x

Griffin, J. M., \& Tang, D. Y. (2011). Did credit rating agencies make unbiased assumptions on CDOs? In American Economic Review (Vol. 101, pp. 125-130). https://doi.org/10.1257/aer.101.3.125

Griffin, J. M., \& Tang, D. Y. (2012). Did Subjectivity Play a Role in CDO Credit Ratings? Journal of Finance, 67(4), 1293-1328. https://doi.org/10.1111/j.1540-6261.2012.01748.x

Hand, J., Holthausen, R., \& Leftwich, R. (1992). The Effect of Bond Rating Agency Announcements on Bond and Stock Prices. Journal of Finance, 47(2), 733-752.

Harrison, J. M., \& Kreps, D. M. (1978). Speculative Investor Behavior in a Stock Market with Heterogeneous Expectations. The Quarterly Journal of Economics, 92(2), 323-336. https://doi.org/10.2307/1884166

Holthausen, R., \& Leftwich, R. (1986). The Effect of Bond Rating Changes on Common Stock Prices. Journal of Financial Economics, 17, 57-89.

Horton, J., Serafeim, G., \& Wu, S. (2017). Career concerns of banking analysts. Journal of Accounting and Economics, 63(2-3), 231-252. https://doi.org/10.1016/j.jacceco.2017.03.003

Hull, J., Predescu, M., \& White, A. (2004). The relationship between credit default swap spreads, bond yields, and credit rating announcements. Journal of Banking and Finance, 28(11), 27892811. https://doi.org/10.1016/j.jbankfin.2004.06.010

Jegadeesh, N., \& Kim, W. (2006). Value of analyst recommendations: International evidence. Journal of Financial Markets, 9(3), 274-309. https://doi.org/10.1016/j.finmar.2006.05.001

Jiang, G. J., \& Kim, W. (2016). Evaluating analysts' value: evidence from recommendation revisions around stock price jumps. The European Journal of Finance, 22(3), 167-194. https://doi.org/10.1080/1351847X.2014.960979

Jorion, P., Liu, Z., \& Shi, C. (2005). Informational effects of regulation FD: Evidence from rating agencies. Journal of Financial Economics, 76(2), 309-330. https://doi.org/10.1016/j.jfineco.2004.05.001 
Kliger, D., \& Sarig, O. (2000). The Information Value of Bond Ratings. The Journal of Finance, 55(6), 2879-2902. https://doi.org/10.1111/0022-1082.00311

Laeven, L., \& Levine, R. (2009). Bank governance, regulation and risk taking. Journal of Financial Economics, 93(2), 259-275. https://doi.org/10.1016/j.jfineco.2008.09.003

Liu, P., Smith, S., \& Syed, A. (1990). Stock Price Reactions to The Wall Street Journal â€ $€^{\mathrm{TM}} \mathrm{S}$ Securities Recommendations. The Journal of Financial and Quantitative Analysis, 25(3), 399410.

Maxwell, W. F., \& Stephens, C. P. (2003). The Wealth Effects of Repurchases on Bondholders. Journal of Finance, 58(2), 895-919. https://doi.org/10.1111/1540-6261.00550

Menéndez-Requejo, S. (2005). Market valuation of the analysts' recommendations: the Spanish stock market. Applied Financial Economics, 15(7), 509-518. https://doi.org/10.1080/09603100500056585

Mengle, D. (2007). Credit Derivatives: An Overview. Economic Review - Federal Reserve Bank of Atlanta, 92(4), 1-24. https://doi.org/10.1007/s10690-007-9055-8

Minor, D. B., \& Morgan, J. (2011). CSR as reputation insurance: Primum non nocere. California Management Review, 53(3), 40-59. https://doi.org/10.1525/cmr.2011.53.3.40

Mokoaleli-Mokoteli, T., Taffler, R. J., \& Agarwal, V. (2009). Behavioural bias and conflicts of interest in analyst stock recommendations. Journal of Business Finance and Accounting, 36(34), 384-418. https://doi.org/10.1111/j.1468-5957.2009.02125.x

Norden, L., \& Weber, M. (2004). Informational efficiency of credit default swap and stock markets: The impact of credit rating announcements. Journal of Banking and Finance, 28(11), 28132843. https://doi.org/10.1016/j.jbankfin.2004.06.011

Perry, J., \& Fontnouvelle, P. De. (2005). Measuring reputational risk: The market reaction to operational loss announcements. SSRN eLibrary, 1-33. https://doi.org/10.2139/ssrn.861364

Pfarrer, M., Pollock, T., \& Rindova, V. (2010). A tale of two assets: The effects of firm reputation and celebrity on earnings surprises and Investors' reactions. Academy of Management Journal, 53(5), 1131-1152. https://doi.org/10.5465/AMJ.2010.54533222

Plunus, S., Gillet, R., \& Huebner, G. (2012). Reputational damage of operational loss on the bond market: Evidence from the financial industry. International Review of Financial Analysis, 24, 66-73. https://doi.org/10.1016/j.irfa.2012.07.007

Rhee, M., \& Haunschild, P. R. (2006). The Liability of Good Reputation: A Study of Product Recalls in the U.S. Automobile Industry. Organization Science, 17(1), 101-117. https://doi.org/10.1287/orsc.1050.0175 
Schnietz, K. E., \& Epstein, M. J. (2005). Exploring the Financial Value of a Reputation for Corporate Social Responsibility During a Crisis. Corporate Reputation Review, 7(4), 327-345. https://doi.org/10.1057/palgrave.crr.1540230

Srivastav, A., \& Hagendorff, J. (2016). Corporate Governance and Bank Risk-taking. Corporate Governance: An International Review, 24(3), 334-345. https://doi.org/10.1111/corg.12133

Sturm, P. (2013a). How much should creditors worry about operational risk? The credit default swap spread reaction to operational loss events. Journal of Operational Risk, 8(4), 3-25.

Sturm, P. (2013b). Operational and reputational risk in the European banking industry: The market reaction to operational risk events. Journal of Economic Behavior and Organization, 85(1), 191-206. https://doi.org/10.1016/j.jebo.2012.04.005

Wade, J. B., Porac, J. F., Pollock, T. G., \& Graffin, S. D. (2006). The burden of celebrity: The impact of CEO certification contests on CEO pay and performance. Academy of Management Journal. https://doi.org/10.5465/AMJ.2006.22083021

Wang, J., Svec, J., \& Peat, M. (2014). The information content of ratings: An analysis of Australian credit default swap spreads. Abacus, 50(1), 56-75. https://doi.org/10.1111/abac.12022

Wang, T., \& Hsu, C. (2013). Board composition and operational risk events of financial institutions. Journal of Banking and Finance, 37(6), 2042-2051. https://doi.org/10.1016/j.jbankfin.2013.01.027

Wormac, K. (1996). Do Brokerage Analysts' Recommendations Have Investment Value? The Journal of Finance, 51(1), 137-167 


\section{Table 1: Sample Selection Procedure}

This table reports the selection criteria and procedure of our final sample comprising operational risk event announcements in publicly listed financial institutions incorporated in USA, Europe, Canada, Australia, and Japan during the post-global financial crisis (post-GFC) period (2010 $-2014)$.

\section{Sample Selection Procedure}

Observations

Complete ORIC Database (March 2015)

(-) Announcements before $1^{\text {st }}$ January 2010

(-) Announcements after 31 ${ }^{\text {st }}$ December 2014

(-) Announcements in non-financial Firms

(-) Announcements in loss firms not headquartered in USA, Europe, Canada, Australia, and Japan

(-) Announcements which have no clear operational risk classification (event type or business line)

(-) Announcements whose dates are not confirmed or full-text press articles not found

(-) Announcements in private financial firms

(-) Announcements overlapping with earnings announcements or credit rating announcements (two trading weeks before and after the operational risk announcement)

(-) Announcements with "Underperform" stock recommendation

(-) Announcements in loss firms with incomplete DataStream and Bloomberg data 
Table 2: Composition of the Final Sample

This table reports the composition of our final sample comprising operational risk event announcements in publicly listed financial institutions incorporated in USA, Europe, Canada, Australia, and Japan during the post-global financial crisis (post-GFC) period (2010 - 2014).

Panel A: By Country

\begin{tabular}{|lcc|}
\hline Country & Frequency & Percent\% \\
\hline Australia & 13 & 5.1 \\
Austria & 2 & 0.78 \\
Belgium & 1 & 0.39 \\
Canada & 2 & 0.78 \\
France & 3 & 1.18 \\
Germany & 14 & 5.49 \\
Hungary & 2 & 0.78 \\
Ireland & 1 & 0.39 \\
Israel & 1 & 0.39 \\
Italy & 1 & 0.39 \\
Japan & 30 & 11.76 \\
Netherlands & 3 & 1.18 \\
Norway & 1 & 0.39 \\
Russian Federation & 2 & 0.78 \\
Spain & 2 & 0.78 \\
Sweden & 2 & 0.78 \\
Switzerland & 18 & 7.06 \\
Turkey & 6 & 2.35 \\
United Kingdom & 69 & 27.06 \\
United States & 82 & 32.16 \\
Total & 255 & 100 \\
\hline
\end{tabular}


Table 2: Composition of the Final Sample

This table reports the composition of our final sample comprising operational risk event announcements in publicly listed financial institutions incorporated in USA, Europe, Canada, Australia, and Japan during the post-global financial crisis (post-GFC) period (2010 - 2014).

Panel B: By Industry Type

\begin{tabular}{|lcc|}
\hline Industry Type & Frequency & Percent\% \\
\hline Banks & 55 & 21.57 \\
Consumer Finance & 3 & 1.18 \\
Corporate Banking & 1 & 0.39 \\
Diversified Banks & 117 & 45.88 \\
Institutional Brokerage & 19 & 7.45 \\
Institutional Trust, Fiduciary \& Custody & 5 & 1.96 \\
Insurance Brokers & 1 & 0.39 \\
Investment Income - Life Insurance & 1 & 0.39 \\
Investment Management & 3 & 1.18 \\
Life Insurance & 7 & 2.75 \\
Mortgage Finance & 3 & 1.18 \\
Other Financial Services & 2 & 0.78 \\
P\&C Insurance & 6 & 2.35 \\
Retail Banking & 14 & 5.49 \\
Trading \& Principal Investment & 4 & 1.57 \\
Wealth Management & 14 & 5.49 \\
Total & 255 & 100 \\
\hline
\end{tabular}


Table 2: Composition of the Final Sample

This table reports the composition of our final sample comprising operational risk event announcements in publicly listed financial institutions incorporated in USA, Europe, Canada, Australia, and Japan during the post-global financial crisis (post-GFC) period (2010 - 2014).

Panel C: By Stock Recommendation

\begin{tabular}{|lcc|}
\hline Stock Recommendation & Frequency & Percent\% \\
\hline Buy & 108 & 42.35 \\
Hold & 147 & 57.65 \\
Total & 255 & 100 \\
\hline
\end{tabular}


Table 2: Composition of the Final Sample

This table reports the composition of our final sample comprising operational risk event announcements in publicly listed financial institutions incorporated in USA, Europe, Canada, Australia, and Japan during the post-global financial crisis (post-GFC) period (2010 - 2014).

Panel D: By Credit Rating

\begin{tabular}{|c|c|c|c|}
\hline Credit Rating Grade & Credit Rating Level & Frequency & Percent \% \\
\hline \multirow{7}{*}{ Investment Grade } & AA & 5 & 2.24 \\
\hline & AA- & 10 & 4.48 \\
\hline & $A+$ & 36 & 16.14 \\
\hline & A & 43 & 19.28 \\
\hline & A- & 76 & 34.08 \\
\hline & $\mathrm{BBB}+$ & 18 & 8.07 \\
\hline & $\mathrm{BBB}$ & 9 & 4.04 \\
\hline \multirow{4}{*}{ Speculative Grade } & $\mathrm{BB}+$ & 11 & 4.93 \\
\hline & $\mathrm{BB}$ & 7 & 3.14 \\
\hline & B- & 8 & 3.59 \\
\hline & Total & 223 & 100 \\
\hline
\end{tabular}


Table 3: Descriptive Statistics

This table reports the descriptive statistics for the variables tested. Variables description is reported in the appendix.

\begin{tabular}{|c|c|c|c|c|c|c|}
\hline Variables & Obs & Min & Median & Mean & StDev & Max \\
\hline$R C A R(-5,+5)$ & 255 & -0.2174 & -0.0024 & 0.0082 & 0.0695 & 0.5334 \\
\hline $\operatorname{Pr}\left(R C A R_{i j}(-5,+5)<0\right)$ & 255 & 0 & 1 & 0.5137 & 0.5008 & 1 \\
\hline $\operatorname{CASC}(-5,+5)$ & 135 & -31 & 1.78 & 5.58 & 16.3 & 40.51 \\
\hline $\operatorname{CARSC}(-5,+5)$ & 135 & -0.2178 & 0.0253 & 0.0213 & 0.082 & 0.218 \\
\hline Buy Stock Recommendation & 255 & 0 & 0 & 0.42 & 0.5 & 1 \\
\hline StDev Stock Recommendation & 255 & 0 & 0.93 & 0.91 & 0.2 & 1.41 \\
\hline Credit Rating Level & 223 & 0.25 & 0.69 & 1.69 & 3.81 & 28.76 \\
\hline Speculative Grade & 223 & 0 & 0 & 0.12 & 0.32 & 1 \\
\hline Analyst Coverage & 255 & 1 & 23 & 21.57 & 8.55 & 37 \\
\hline Loss Disclosed Dum & 255 & 0 & 1 & 0.69 & 0.46 & 1 \\
\hline Firm Recognized Dum & 255 & 0 & 0 & 0.33 & 0.47 & 1 \\
\hline Regulatory Announced Dum & 255 & 0 & 1 & 0.56 & 0.50 & 1 \\
\hline Settlement Dum & 255 & 0 & 0 & 0.16 & 0.37 & 1 \\
\hline Different Country Dum & 255 & 0 & 0 & 0.26 & 0.44 & 1 \\
\hline Top Figures Dum & 255 & 0 & 0 & 0.08 & 0.27 & 1 \\
\hline Basel Business Line Dum & 255 & 0 & 1 & 0.78 & 0.41 & 1 \\
\hline Fraud Dum & 255 & 0 & 0 & 0.13 & 0.35 & 1 \\
\hline U.S. Firm Dum & 255 & 0 & 0 & 0.32 & 0.48 & 1 \\
\hline StDev Stock Return & 255 & 0.0084 & 0.0202 & 0.0223 & 0.0103 & 0.0766 \\
\hline Beta & 255 & 0.26 & 1.72 & 1.80 & 0.71 & 4.46 \\
\hline Float & 255 & 0 & 92 & 78.03 & 27.60 & 100 \\
\hline Trading Volume & 255 & 25 & 11732 & 25431 & 46980 & 333408 \\
\hline Total Assets & 255 & 756 & 1079727 & 1189585 & 906101 & 2867222 \\
\hline$R O A$ & 255 & -3.59 & 0.37 & 0.37 & 1.08 & 7.2 \\
\hline Leverage & 255 & 0 & 1.5 & 1.65 & 1.05 & 5.46 \\
\hline Market to Book Ratio & 255 & 0.32 & 0.9 & 1.04 & 0.69 & 4.79 \\
\hline GDP Per Capita & 255 & 10646 & 48374 & 49157 & 14009 & 100575 \\
\hline
\end{tabular}




\section{Table 4: Univariate Analysis}

This table reports the mean comparison tests of the severity and probability of reputational damage around operational risk announcements in financial institutions for different types of analysts' stock recommendations and credit ratings. ${ }^{*} \mathrm{p}<0.1 ;{ }^{* *} \mathrm{p}<0.05 ;{ }^{* * *} \mathrm{p}<0.01$

Panel A: Equity-based Reputational Effects of Stock Recommendations

\begin{tabular}{|l|ccc|ccc|}
\hline & Buy & Hold & Difference & $\begin{array}{c}\text { Low } \\
\text { Dispersion }\end{array}$ & $\begin{array}{c}\text { High Dispersion } \\
\text { Difference }\end{array}$ \\
\hline Mean RCAR $(-\mathbf{5},+5)$ & -0.0000373 & 0.0178959 & -0.0179332 & -0.0013943 & 0.0164647 & -0.0178591 \\
& & & $(-1.9154)^{*}$ & & & $(-2.0581)^{* *}$ \\
Probability of Reputational Damage & 0.5555556 & 0.4140625 & 0.1414931 & 0.5932203 & 0.4452555 & 0.1479649 \\
& & & & & & $1.1804)^{* *}$ \\
Observations & 108 & 147 & & 137 & 118 \\
\hline
\end{tabular}

$* p<0.1 ; * * p<0.05 ; * * * p<0.01$ 


\section{Table 4: Univariate Analysis}

This table reports the mean comparison tests of the severity and probability of reputational damage around operational risk announcements in financial institutions for different types of analysts' stock recommendations, credit rating levels and credit rating changes. ${ }^{*} \mathrm{p}<0.1 ; * * \mathrm{p}<0.05 ; * * * \mathrm{p}<0.01$

\section{Panel B: Debt-based Reputational Effects of Credit Ratings}

\begin{tabular}{|c|c|c|c|c|c|c|}
\hline & $\begin{array}{c}\text { Low Credit } \\
\text { Rating }\end{array}$ & $\begin{array}{l}\text { High Credit } \\
\text { Rating }\end{array}$ & Difference & $\begin{array}{l}\text { Speculative } \\
\text { Grade }\end{array}$ & $\begin{array}{l}\text { Investment } \\
\text { Grade }\end{array}$ & Difference \\
\hline Mean $\operatorname{CASC}(-5,+5)$ & 10.46766 & -0.5404946 & $\begin{array}{c}11.00815 \\
(4.1257) * * *\end{array}$ & 40.5132 & 0.2000611 & $\begin{array}{c}40.31314 \\
(18.1377)^{* * *}\end{array}$ \\
\hline Mean $\operatorname{CARSC}(-5,+5$ & 0.0368617 & 0.0018096 & $\begin{array}{l}0.0350521 \\
(2.5178)^{* *}\end{array}$ & 0.121783 & 0.0058214 & $\begin{array}{c}0.1159616 \\
(6.3567)^{* * *}\end{array}$ \\
\hline Observations & 75 & 60 & & 18 & 117 & \\
\hline
\end{tabular}

$* p<0.1 ; * * p<0.05 ; * * * p<0.01$ 


\section{Table 5: Equity-based Reputational Effects of Analysts' Stock Recommendations around Operational Risk Announcements}

This table reports the results of the OLS regression model estimating the equity-based reputational impact $R C A R(-5,+5)$ in Models (1), (3) and (5) and the logit model estimating the log-odds of equity-based reputational damage $\ln \left(\operatorname{odds}\left(\operatorname{RCAR}_{i j}(-5,+5)<0\right)\right)$ in Models (2), (4) and (6) around operational risk event announcements in publicly listed financial institutions incorporated in USA, Europe, Canada, Australia, and Japan during the postglobal financial crisis (post-GFC) period $(2010$ - 2014). Variables description is reported in the appendix. Heteroscedasticity-robust standard errors and two-tailed t-tests are used to infer the significance of the regression coefficients. $* \mathrm{p}<0.1 ; * * \mathrm{p}<0.05 ; * * * \mathrm{p}<0.01$

Panel A: Buy Stock Recommendation

\begin{tabular}{|c|c|c|c|c|c|c|}
\hline \multirow[b]{2}{*}{ Variables } & (1) & (2) & (3) & (4) & (5) & (6) \\
\hline & $\operatorname{RCAR}(-5,+5)$ & $\begin{array}{c}\quad \ln (\text { odds } \\
\left(\text { RCAR }_{i j}(-5,+5)\right. \\
<0))\end{array}$ & $\operatorname{RCAR}(-5,+5)$ & $\begin{array}{l}\quad \ln (\text { odds } \\
\left(R_{C A R_{i j}}(-5,+5)\right. \\
<0))\end{array}$ & $\operatorname{RCAR}(-5,+5)$ & $\begin{array}{l}\quad \ln (\text { odds } \\
\left(\text { RCAR }_{i j}(-5,+5)\right. \\
<0))\end{array}$ \\
\hline Buy Stock Recommendation & $\begin{array}{c}-0.020017 \\
(2.28)^{* *}\end{array}$ & $\begin{array}{l}0.656676 \\
(2.13)^{* *}\end{array}$ & $\begin{array}{c}-0.011373 \\
(1.05)\end{array}$ & $\begin{array}{l}0.836043 \\
(2.25)^{* *}\end{array}$ & $\begin{array}{c}-0.011436 \\
(1.06)\end{array}$ & $\begin{array}{c}0.839954 \\
(2.26)^{* *}\end{array}$ \\
\hline Credit Rating Level & & & $\begin{array}{c}-0.000680 \\
(0.31)\end{array}$ & $\begin{array}{c}-0.005610 \\
(0.12)\end{array}$ & & \\
\hline Speculative Grade & & & & & $\begin{array}{c}-0.031043 \\
(1.45)\end{array}$ & $\begin{array}{l}1.800284 \\
(1.98)^{* * *}\end{array}$ \\
\hline Analyst Coverage & $\begin{array}{c}0.000519 \\
(0.66)\end{array}$ & $\begin{array}{c}-0.024317 \\
(0.93)\end{array}$ & $\begin{array}{c}0.001244 \\
(1.21)\end{array}$ & $\begin{array}{c}-0.017390 \\
(0.57)\end{array}$ & $\begin{array}{c}0.001254 \\
(1.21)\end{array}$ & $\begin{array}{c}-0.015909 \\
(0.52)\end{array}$ \\
\hline Loss Disclosed Dum & $\begin{array}{c}0.001180 \\
(0.14)\end{array}$ & $\begin{array}{l}0.542829 \\
(1.66)^{*}\end{array}$ & $\begin{array}{c}0.005804 \\
(0.70)\end{array}$ & $\begin{array}{c}0.543956 \\
(1.50)\end{array}$ & $\begin{array}{c}0.008166 \\
(0.93)\end{array}$ & $\begin{array}{c}0.426968 \\
(1.17)\end{array}$ \\
\hline Firm Recognized Dum & $\begin{array}{c}-0.012752 \\
(0.93)\end{array}$ & $\begin{array}{c}0.006993 \\
(0.02)\end{array}$ & $\begin{array}{c}-0.015456 \\
(1.10)\end{array}$ & $\begin{array}{c}0.061312 \\
(0.14)\end{array}$ & $\begin{array}{c}-0.018727 \\
(1.29)\end{array}$ & $\begin{array}{c}0.276249 \\
(0.60)\end{array}$ \\
\hline Regulatory Announced Dum & $\begin{array}{c}-0.010159 \\
(0.99)\end{array}$ & $\begin{array}{c}0.186968 \\
(0.64)\end{array}$ & $\begin{array}{c}-0.008086 \\
(0.76)\end{array}$ & $\begin{array}{c}0.227981 \\
(0.70)\end{array}$ & $\begin{array}{c}-0.006249 \\
(0.59)\end{array}$ & $\begin{array}{c}0.130291 \\
(0.39)\end{array}$ \\
\hline Settlement Dum & $\begin{array}{c}0.010851 \\
(0.86)\end{array}$ & $\begin{array}{c}-0.684883 \\
(1.40)\end{array}$ & $\begin{array}{c}0.011722 \\
(0.86)\end{array}$ & $\begin{array}{c}-0.919533 \\
(1.72)^{*}\end{array}$ & $\begin{array}{c}0.011221 \\
(0.83)\end{array}$ & $\begin{array}{c}-0.911095 \\
(1.70)^{*}\end{array}$ \\
\hline Different Country Dum & $\begin{array}{c}-0.003345 \\
(0.31)\end{array}$ & $\begin{array}{c}0.006814 \\
(0.02)\end{array}$ & $\begin{array}{c}0.001843 \\
(0.15)\end{array}$ & $\begin{array}{c}-0.217523 \\
(0.50)\end{array}$ & $\begin{array}{c}-0.000777 \\
(0.06)\end{array}$ & $\begin{array}{c}-0.076840 \\
(0.18)\end{array}$ \\
\hline Top Figures Dum & $\begin{array}{c}-0.008715 \\
(0.22)\end{array}$ & $\begin{array}{c}-0.757437 \\
(1.26)\end{array}$ & $\begin{array}{c}0.003045 \\
(0.06)\end{array}$ & $\begin{array}{c}-1.006443 \\
(1.42)\end{array}$ & $\begin{array}{c}0.002361 \\
(0.05)\end{array}$ & $\begin{array}{c}-1.064053 \\
(1.52)\end{array}$ \\
\hline Basel Business Line Dum & $\begin{array}{c}-0.011693 \\
(0.86)\end{array}$ & $\begin{array}{c}0.171760 \\
(0.48)\end{array}$ & $\begin{array}{c}-0.011375 \\
(0.71)\end{array}$ & $\begin{array}{c}0.096965 \\
(0.24)\end{array}$ & $\begin{array}{c}-0.008371 \\
(0.53)\end{array}$ & $\begin{array}{c}-0.068955 \\
(0.17)\end{array}$ \\
\hline Fraud Dum & $\begin{array}{c}-0.001103 \\
(0.08)\end{array}$ & $\begin{array}{c}0.134262 \\
(0.27)\end{array}$ & $\begin{array}{c}0.007625 \\
(0.57)\end{array}$ & $\begin{array}{c}-0.180510 \\
(0.33)\end{array}$ & $\begin{array}{c}0.006123 \\
(0.42)\end{array}$ & $\begin{array}{c}-0.175547 \\
(0.32)\end{array}$ \\
\hline U.S. Firm Dum & $\begin{array}{c}0.000027 \\
(0.00)\end{array}$ & $\begin{array}{c}-0.046011 \\
(0.11)\end{array}$ & $\begin{array}{c}0.008240 \\
(0.61)\end{array}$ & $\begin{array}{c}-0.348368 \\
(0.73)\end{array}$ & $\begin{array}{c}0.005435 \\
(0.39)\end{array}$ & $\begin{array}{c}-0.210784 \\
(0.43)\end{array}$ \\
\hline StDev Stock Return & $\begin{array}{c}1.110933 \\
(1.72)^{*}\end{array}$ & $\begin{array}{c}-1.491603 \\
(0.09)\end{array}$ & $\begin{array}{c}0.667923 \\
(0.93)\end{array}$ & $\begin{array}{l}5.559275 \\
(0.30)\end{array}$ & $\begin{array}{c}0.821027 \\
(1.08)\end{array}$ & $\begin{array}{c}-1.060144 \\
(0.05)\end{array}$ \\
\hline Beta & $\begin{array}{c}0.011041 \\
(1.48)\end{array}$ & $\begin{array}{c}-0.360671 \\
(1.25)\end{array}$ & $\begin{array}{c}0.009407 \\
(0.88)\end{array}$ & $\begin{array}{c}-0.491178 \\
(1.45)\end{array}$ & $\begin{array}{c}0.011429 \\
(1.13)\end{array}$ & $\begin{array}{c}-0.640884 \\
(1.85)^{*}\end{array}$ \\
\hline Float & $\begin{array}{c}-0.000155 \\
(0.75)\end{array}$ & $\begin{array}{c}0.002542 \\
(0.42)\end{array}$ & $\begin{array}{c}-0.000396 \\
(0.97)\end{array}$ & $\begin{array}{c}-0.003264 \\
(0.33)\end{array}$ & $\begin{array}{c}-0.000390 \\
(0.97)\end{array}$ & $\begin{array}{c}-0.002717 \\
(0.26)\end{array}$ \\
\hline Ln(Trading Volume) & $\begin{array}{c}-0.001976 \\
(0.50)\end{array}$ & $\begin{array}{c}0.067012 \\
(0.72)\end{array}$ & $\begin{array}{c}-0.000420 \\
(0.09)\end{array}$ & $\begin{array}{c}0.060984 \\
(0.57)\end{array}$ & $\begin{array}{c}-0.000314 \\
(0.06)\end{array}$ & $\begin{array}{c}0.060811 \\
(0.56)\end{array}$ \\
\hline Ln(Total Assets) & $\begin{array}{c}0.010129 \\
(1.84)^{*}\end{array}$ & $\begin{array}{c}-0.159188 \\
(1.01)\end{array}$ & $\begin{array}{c}0.007427 \\
(1.01)\end{array}$ & $\begin{array}{c}-0.289909 \\
(1.41)\end{array}$ & $\begin{array}{c}0.004159 \\
(0.58)\end{array}$ & $\begin{array}{c}-0.051396 \\
(0.22)\end{array}$ \\
\hline$R O A$ & $\begin{array}{l}0.013355 \\
(2.27)^{* *}\end{array}$ & $\begin{array}{c}-0.284136 \\
(1.38)\end{array}$ & $\begin{array}{c}0.002780 \\
(0.32)\end{array}$ & $\begin{array}{c}-0.078834 \\
(0.30)\end{array}$ & $\begin{array}{c}0.001125 \\
(0.15)\end{array}$ & $\begin{array}{c}0.001656 \\
(0.00)\end{array}$ \\
\hline Leverage & $\begin{array}{c}0.002556 \\
(0.37)\end{array}$ & $\begin{array}{c}-0.078426 \\
(0.47)\end{array}$ & $\begin{array}{c}0.003821 \\
(0.53)\end{array}$ & $\begin{array}{c}-0.161643 \\
(0.87)\end{array}$ & $\begin{array}{c}0.003076 \\
(0.43)\end{array}$ & $\begin{array}{c}-0.127398 \\
(0.71)\end{array}$ \\
\hline Market to Book Ratio & $\begin{array}{c}0.006525 \\
(0.82)\end{array}$ & $\begin{array}{c}-0.037017 \\
(0.13)\end{array}$ & $\begin{array}{c}0.011467 \\
(1.01)\end{array}$ & $\begin{array}{c}-0.091870 \\
(0.28)\end{array}$ & $\begin{array}{c}0.010677 \\
(1.03)\end{array}$ & $\begin{array}{c}-0.000627 \\
(0.00)\end{array}$ \\
\hline GDP Per Capita & $\begin{array}{c}0.000000 \\
(0.20)\end{array}$ & $\begin{array}{c}0.000006 \\
(0.50)\end{array}$ & $\begin{array}{c}0.000000 \\
(0.43)\end{array}$ & $\begin{array}{c}0.000025 \\
(1.33)\end{array}$ & $\begin{array}{c}0.000000 \\
(0.41)\end{array}$ & $\begin{array}{c}0.000028 \\
(1.36)\end{array}$ \\
\hline Constant & $\begin{array}{c}-0.145988 \\
(2.16)^{* *}\end{array}$ & $\begin{array}{c}1.812196 \\
(0.94)\end{array}$ & $\begin{array}{c}-0.135531 \\
(1.47)\end{array}$ & $\begin{array}{c}3.537047 \\
(1.31)\end{array}$ & $\begin{array}{c}-0.096146 \\
(1.10)\end{array}$ & $\begin{array}{c}0.275789 \\
(0.10)\end{array}$ \\
\hline$R 2$ & 0.12 & 0.05 & 0.10 & 0.08 & 0.11 & 0.09 \\
\hline$N$ & 255 & 255 & 223 & 223 & 223 & 223 \\
\hline
\end{tabular}

$* p<0.1 ; * * p<0.05 ; * * * p<0.01$ 


\section{Table 5: Equity-based Reputational Effects of Analysts' Stock Recommendations around Operational Risk Announcements}

This table reports the results of the OLS regression model estimating the equity-based reputational impact $R C A R(-5,+5)$ in Models (1), (3) and (5) and the logit model estimating the log-odds of equity-based reputational damage $\ln \left(\operatorname{odds}\left(\operatorname{RCAR}_{i j}(-5,+5)<0\right)\right)$ in Models (2), (4) and (6) around operational risk event announcements in publicly listed financial institutions incorporated in USA, Europe, Canada, Australia, and Japan during the postglobal financial crisis (post-GFC) period $(2010$ - 2014). Variables description is reported in the appendix. Heteroscedasticity-robust standard errors and two-tailed t-tests are used to infer the significance of the regression coefficients. $* \mathrm{p}<0.1 ; * * \mathrm{p}<0.05 ; * * * \mathrm{p}<0.01$

Panel B: Dispersion of Stock Recommendations

\begin{tabular}{|c|c|c|c|c|c|c|}
\hline & (1) & (2) & (3) & (4) & (5) & (6) \\
\hline Variables & $\operatorname{RCAR}(-5,+5)$ & $\begin{array}{l}\quad \ln (\text { odds } \\
\left(\operatorname{RCAR}_{i j}(-5,+5)\right. \\
<0))\end{array}$ & $\operatorname{RCAR}(-5,+5)$ & $\begin{array}{l}\quad \ln (\text { odds } \\
\left(R_{C A R_{i j}}(-5,+5)\right. \\
<0))\end{array}$ & $\operatorname{RCAR}(-5,+5)$ & $\begin{array}{l}\quad \ln (\text { odds } \\
\left(R_{C A R_{i j}}(-5,+5)\right. \\
<0))\end{array}$ \\
\hline StDev Stock Recommendation & $\begin{array}{c}-0.001452 \\
(0.04)\end{array}$ & $\begin{array}{c}-0.081644 \\
(0.10)\end{array}$ & $\begin{array}{c}0.057677 \\
(0.97)\end{array}$ & $\begin{array}{c}-1.244970 \\
(0.97)\end{array}$ & $\begin{array}{l}0.046051 \\
(0.73)\end{array}$ & $\begin{array}{c}-0.234821 \\
(0.18)\end{array}$ \\
\hline Credit Rating Level & & & $\begin{array}{c}0.000165 \\
(0.09)\end{array}$ & $\begin{array}{c}-0.026859 \\
(0.55)\end{array}$ & & \\
\hline Speculative Grade & & & & & $\begin{array}{c}-0.021625 \\
(1.00)\end{array}$ & $\begin{array}{l}1.746896 \\
(1.75)^{*}\end{array}$ \\
\hline Analyst Coverage & $\begin{array}{l}0.000501 \\
(0.71)\end{array}$ & $\begin{array}{c}-0.022512 \\
(0.88)\end{array}$ & $\begin{array}{c}0.000962 \\
(1.11)\end{array}$ & $\begin{array}{c}-0.009002 \\
(0.31)\end{array}$ & $\begin{array}{c}0.001003 \\
(1.16)\end{array}$ & $\begin{array}{c}-0.012038 \\
(0.40)\end{array}$ \\
\hline Loss Disclosed Dum & $\begin{array}{c}0.002893 \\
(0.34)\end{array}$ & $\begin{array}{l}0.473590 \\
(1.46)\end{array}$ & $\begin{array}{c}0.009008 \\
(1.00)\end{array}$ & $\begin{array}{c}0.434279 \\
(1.20)\end{array}$ & $\begin{array}{c}0.010057 \\
(1.09)\end{array}$ & $\begin{array}{c}0.365807 \\
(1.02)\end{array}$ \\
\hline Firm Recognized Dum & $\begin{array}{c}-0.015348 \\
(1.11)\end{array}$ & $\begin{array}{c}0.067976 \\
(0.16)\end{array}$ & $\begin{array}{c}-0.013210 \\
(0.96)\end{array}$ & $\begin{array}{c}0.019073 \\
(0.04)\end{array}$ & $\begin{array}{c}-0.016441 \\
(1.15)\end{array}$ & $\begin{array}{c}0.270369 \\
(0.59)\end{array}$ \\
\hline Regulatory Announced Dum & $\begin{array}{c}-0.011823 \\
(1.19)\end{array}$ & $\begin{array}{c}0.236191 \\
(0.80)\end{array}$ & $\begin{array}{c}-0.005910 \\
(0.61)\end{array}$ & $\begin{array}{c}0.251997 \\
(0.76)\end{array}$ & $\begin{array}{c}-0.005419 \\
(0.55)\end{array}$ & $\begin{array}{c}0.224098 \\
(0.68)\end{array}$ \\
\hline Settlement Dum & $\begin{array}{c}0.011362 \\
(0.88)\end{array}$ & $\begin{array}{c}-0.671250 \\
(1.37)\end{array}$ & $\begin{array}{c}0.009251 \\
(0.67)\end{array}$ & $\begin{array}{c}-0.855333 \\
(1.59)\end{array}$ & $\begin{array}{c}0.009523 \\
(0.70)\end{array}$ & $\begin{array}{c}-0.886649 \\
(1.68)^{*}\end{array}$ \\
\hline Different Country Dum & $\begin{array}{c}-0.005398 \\
(0.50)\end{array}$ & $\begin{array}{c}0.050149 \\
(0.13)\end{array}$ & $\begin{array}{c}0.002897 \\
(0.24)\end{array}$ & $\begin{array}{c}-0.253907 \\
(0.61)\end{array}$ & $\begin{array}{c}0.000777 \\
(0.06)\end{array}$ & $\begin{array}{c}-0.104719 \\
(0.25)\end{array}$ \\
\hline Top Figures Dum & $\begin{array}{c}-0.012185 \\
(0.31)\end{array}$ & $\begin{array}{c}-0.628695 \\
(1.07)\end{array}$ & $\begin{array}{c}0.002624 \\
(0.06)\end{array}$ & $\begin{array}{c}-0.885247 \\
(1.33)\end{array}$ & $\begin{array}{c}0.002746 \\
(0.06)\end{array}$ & $\begin{array}{c}-0.918595 \\
(1.38)\end{array}$ \\
\hline Basel Business Line Dum & $\begin{array}{c}-0.010765 \\
(0.78)\end{array}$ & $\begin{array}{c}0.137312 \\
(0.39)\end{array}$ & $\begin{array}{c}-0.011656 \\
(0.71)\end{array}$ & $\begin{array}{c}0.083716 \\
(0.21)\end{array}$ & $\begin{array}{c}-0.009163 \\
(0.56)\end{array}$ & $\begin{array}{c}-0.097847 \\
(0.24)\end{array}$ \\
\hline Fraud Dum & $\begin{array}{l}0.001748 \\
(0.11)\end{array}$ & $\begin{array}{c}0.055339 \\
(0.11)\end{array}$ & $\begin{array}{c}0.006708 \\
(0.47)\end{array}$ & $\begin{array}{c}-0.189841 \\
(0.34)\end{array}$ & $\begin{array}{c}0.006676 \\
(0.45)\end{array}$ & $\begin{array}{c}-0.226245 \\
(0.42)\end{array}$ \\
\hline U.S. Firm Dum & $\begin{array}{c}-0.002332 \\
(0.19)\end{array}$ & $\begin{array}{c}-0.015664 \\
(0.04)\end{array}$ & $\begin{array}{c}0.017068 \\
(1.00)\end{array}$ & $\begin{array}{c}-0.557789 \\
(1.07)\end{array}$ & $\begin{array}{c}0.013366 \\
(0.75)\end{array}$ & $\begin{array}{c}-0.286063 \\
(0.53)\end{array}$ \\
\hline StDev Stock Return & $\begin{array}{l}1.119495 \\
(1.69)^{*}\end{array}$ & $\begin{array}{c}-1.577531 \\
(0.09)\end{array}$ & $\begin{array}{l}0.624937 \\
(0.88)\end{array}$ & $\begin{array}{c}8.025929 \\
(0.44)\end{array}$ & $\begin{array}{l}0.719299 \\
(0.94)\end{array}$ & $\begin{array}{l}1.167485 \\
(0.06)\end{array}$ \\
\hline Beta & $\begin{array}{c}0.011419 \\
(1.30)\end{array}$ & $\begin{array}{c}-0.333420 \\
(1.14)\end{array}$ & $\begin{array}{c}0.003133 \\
(0.28)\end{array}$ & $\begin{array}{c}-0.298315 \\
(0.87)\end{array}$ & $\begin{array}{c}0.006100 \\
(0.54)\end{array}$ & $\begin{array}{c}-0.537028 \\
(1.44)\end{array}$ \\
\hline Float & $\begin{array}{c}-0.000159 \\
(0.75)\end{array}$ & $\begin{array}{c}0.002573 \\
(0.42)\end{array}$ & $\begin{array}{c}-0.000393 \\
(1.15)\end{array}$ & $\begin{array}{c}0.000259 \\
(0.03)\end{array}$ & $\begin{array}{c}-0.000416 \\
(1.21)\end{array}$ & $\begin{array}{c}0.001865 \\
(0.17)\end{array}$ \\
\hline Ln(Trading Volume) & $\begin{array}{c}-0.002831 \\
(0.65)\end{array}$ & $\begin{array}{c}0.088325 \\
(0.99)\end{array}$ & $\begin{array}{c}0.000138 \\
(0.02)\end{array}$ & $\begin{array}{c}0.067889 \\
(0.66)\end{array}$ & $\begin{array}{c}-0.000030 \\
(0.01)\end{array}$ & $\begin{array}{c}0.086957 \\
(0.84)\end{array}$ \\
\hline Ln(Total Assets) & $\begin{array}{c}0.009177 \\
(1.59)\end{array}$ & $\begin{array}{c}-0.113764 \\
(0.73)\end{array}$ & $\begin{array}{c}0.006251 \\
(0.86)\end{array}$ & $\begin{array}{c}-0.218105 \\
(1.08)\end{array}$ & $\begin{array}{c}0.003395 \\
(0.51)\end{array}$ & $\begin{array}{c}0.016670 \\
(0.07)\end{array}$ \\
\hline$R O A$ & $\begin{array}{c}0.010354 \\
(1.71)^{*}\end{array}$ & $\begin{array}{c}-0.158690 \\
(0.87)\end{array}$ & $\begin{array}{c}-0.003274 \\
(0.42)\end{array}$ & $\begin{array}{c}0.183490 \\
(0.69)\end{array}$ & $\begin{array}{c}-0.003352 \\
(0.48)\end{array}$ & $\begin{array}{c}0.219453 \\
(0.60)\end{array}$ \\
\hline Leverage & $\begin{array}{c}0.003166 \\
(0.46)\end{array}$ & $\begin{array}{c}-0.099107 \\
(0.60)\end{array}$ & $\begin{array}{c}0.004084 \\
(0.59)\end{array}$ & $\begin{array}{c}-0.180181 \\
(0.98)\end{array}$ & $\begin{array}{c}0.003707 \\
(0.52)\end{array}$ & $\begin{array}{c}-0.147147 \\
(0.84)\end{array}$ \\
\hline Market to Book Ratio & $\begin{array}{c}0.008585 \\
(1.01)\end{array}$ & $\begin{array}{c}-0.099447 \\
(0.37)\end{array}$ & $\begin{array}{c}0.013905 \\
(1.24)\end{array}$ & $\begin{array}{c}-0.260332 \\
(0.82)\end{array}$ & $\begin{array}{c}0.012591 \\
(1.18)\end{array}$ & $\begin{array}{c}-0.171191 \\
(0.51)\end{array}$ \\
\hline GDP Per Capita & $\begin{array}{c}0.000000 \\
(0.27)\end{array}$ & $\begin{array}{c}0.000005 \\
(0.43)\end{array}$ & $\begin{array}{c}0.000000 \\
(0.54)\end{array}$ & $\begin{array}{c}0.000018 \\
(0.94)\end{array}$ & $\begin{array}{c}0.000000 \\
(0.51)\end{array}$ & $\begin{array}{c}0.000019 \\
(0.97)\end{array}$ \\
\hline Constant & $\begin{array}{c}-0.135927 \\
(1.94)^{*}\end{array}$ & $\begin{array}{c}1.377174 \\
(0.71) \\
\end{array}$ & $\begin{array}{c}-0.176943 \\
(2.12)^{* *}\end{array}$ & $\begin{array}{c}3.779118 \\
(1.26)\end{array}$ & $\begin{array}{c}-0.127062 \\
(1.49)\end{array}$ & $\begin{array}{c}-0.443994 \\
(0.15)\end{array}$ \\
\hline $\mathrm{R} 2$ & 0.11 & 0.04 & 0.11 & 0.06 & 0.11 & 0.08 \\
\hline $\mathrm{N}$ & 255 & 255 & 223 & 223 & 223 & 223 \\
\hline
\end{tabular}

$* p<0.1 ; * * p<0.05 ; * * * p<0.01$ 
Table 6: Debt-based Reputational Effects of Credit Ratings around Operational Risk Announcements

This table reports the results of the 2SLS regression model estimating the debt-based reputational impact $\operatorname{CASC}(-5,+5)$ in Model (2) and $\operatorname{CARSC}(-5,+5)$ in Model (3) around operational risk event announcements in publicly listed financial institutions incorporated in USA, Europe, Canada, Australia, and Japan during the postglobal financial crisis (post-GFC) period (2010 - 2014). Model (1) reports the results of the first-stage regression estimating the endogenous variable $R C A \widehat{R(-5},+5)$. Variables description is reported in the appendix. Heteroscedasticity-robust standard errors and two-tailed t-tests are used to infer the significance of the regression coefficients. $* \mathrm{p}<0.1 ; * * \mathrm{p}<0.05 ; * * * \mathrm{p}<0.01$.

Panel A: Credit Rating Level

\begin{tabular}{|c|c|c|c|}
\hline \multirow{3}{*}{ Variables } & \multirow{2}{*}{$\begin{array}{c}\text { First-stage Regression } \\
\text { (1) }\end{array}$} & \multicolumn{2}{|c|}{ Second-stage Regression } \\
\hline & & (2) & (3) \\
\hline & $\operatorname{RCAR}(-5,+5)$ & $\operatorname{CASC}(-5,+5)$ & $\operatorname{CARSC}(-5,+5)$ \\
\hline Credit Rating Level & $\begin{array}{c}-0.001083 \\
(-0.115)\end{array}$ & $\begin{array}{l}10.065152 \\
(5.726)^{* * *}\end{array}$ & $\begin{array}{c}0.036700 \\
(3.432)^{* * * *}\end{array}$ \\
\hline Analyst Coverage & $\begin{array}{c}0.000604 \\
(0.432)\end{array}$ & $\begin{array}{c}-0.089736 \\
(-0.389)\end{array}$ & $\begin{array}{c}-0.000594 \\
(-0.376)\end{array}$ \\
\hline Loss Disclosed Dum & $\begin{array}{c}0.007644 \\
(0.550)\end{array}$ & $\begin{array}{c}1.174823 \\
(0.568)\end{array}$ & $\begin{array}{c}0.019428 \\
(1.133)\end{array}$ \\
\hline Firm Recognized Dum & $\begin{array}{c}-0.026848 \\
(-1.332)\end{array}$ & $\begin{array}{c}1.969654 \\
(0.578)\end{array}$ & $\begin{array}{c}0.003487 \\
(0.138)\end{array}$ \\
\hline Regulatory Announced Dum & $\begin{array}{c}0.001202 \\
(0.094)\end{array}$ & $\begin{array}{c}-1.569754 \\
(-0.858)\end{array}$ & $\begin{array}{l}-0.023628 \\
(-1.755)^{*}\end{array}$ \\
\hline Settlement Dum & $\begin{array}{c}0.020500 \\
(1.083)\end{array}$ & $\begin{array}{l}-5.412411 \\
(-1.657)^{*}\end{array}$ & $\begin{array}{c}-0.030190 \\
(-1.071)\end{array}$ \\
\hline Different Country Dum & $\begin{array}{c}-0.033981 \\
(-1.633)\end{array}$ & $\begin{array}{c}0.451873 \\
(0.157)\end{array}$ & $\begin{array}{l}0.004700 \\
(0.205)\end{array}$ \\
\hline Top Figures Dum & $\begin{array}{c}-0.037233 \\
(-0.987)\end{array}$ & $\begin{array}{c}9.803622 \\
(1.553)\end{array}$ & $\begin{array}{c}0.037481 \\
(0.738)\end{array}$ \\
\hline Basel Business Line Dum & $\begin{array}{c}-0.027568 \\
(-1.495)\end{array}$ & $\begin{array}{l}7.430481 \\
(1.955)^{*}\end{array}$ & $\begin{array}{c}0.028532 \\
(1.273)\end{array}$ \\
\hline Fraud Dum & $\begin{array}{c}0.015491 \\
(0.886)\end{array}$ & $\begin{array}{c}-5.139993 \\
(-1.516)\end{array}$ & $\begin{array}{l}-0.030015 \\
(-1.062)\end{array}$ \\
\hline U.S. Firm Dum & $\begin{array}{c}-0.028949 \\
(-1.206)\end{array}$ & $\begin{array}{c}-4.340883 \\
(-1.311)\end{array}$ & $\begin{array}{c}-0.029066 \\
(-1.021)\end{array}$ \\
\hline Ln(Total Assets $)$ & $\begin{array}{l}0.040411 \\
(2.381)^{* *}\end{array}$ & $\begin{array}{c}-3.684138 \\
(-1.259)\end{array}$ & $\begin{array}{c}-0.017609 \\
(-0.831)\end{array}$ \\
\hline$R O A$ & $\begin{array}{c}0.008169 \\
(0.440)\end{array}$ & $\begin{array}{l}6.652850 \\
(2.312)^{* *}\end{array}$ & $\begin{array}{l}0.040729 \\
(2.075)^{* *}\end{array}$ \\
\hline Leverage & $\begin{array}{c}0.008167 \\
(0.934)\end{array}$ & $\begin{array}{c}-4.628701 \\
(-2.815)^{* * *}\end{array}$ & $\begin{array}{l}-0.038116 \\
(-3.192)^{* * *}\end{array}$ \\
\hline Market to Book Ratio & $\begin{array}{c}0.025491 \\
(1.342)\end{array}$ & $\begin{array}{c}-1.033899 \\
(-0.313)\end{array}$ & $\begin{array}{c}0.000546 \\
(0.025)\end{array}$ \\
\hline GDP Per Capita & $\begin{array}{c}0.000002 \\
(1.273)\end{array}$ & $\begin{array}{c}0.000004 \\
(0.031)\end{array}$ & $\begin{array}{c}0.000000 \\
(0.515)\end{array}$ \\
\hline Buy Stock Recommendation & $\begin{array}{c}-0.012592 \\
(-1.229)\end{array}$ & & \\
\hline StDev Stock Return & $\begin{array}{c}1.562020 \\
(1.639)\end{array}$ & & \\
\hline Beta & $\begin{array}{l}0.024989 \\
(2.059)^{* *}\end{array}$ & & \\
\hline Float & $\begin{array}{c}-0.000067 \\
(-0.165)\end{array}$ & & \\
\hline Ln(Trading Volume) & $\begin{array}{c}-0.005355 \\
(-1.307)\end{array}$ & & \\
\hline$R C A R(-5,+5)$ & & $\begin{array}{l}82.349901 \\
(1.329)\end{array}$ & $\begin{array}{c}0.449997 \\
(1.082)\end{array}$ \\
\hline Constant & $\begin{array}{c}-0.681504 \\
(-2.638)^{* * *}\end{array}$ & $\begin{array}{c}48.776471 \\
(1.154) \\
\end{array}$ & $\begin{array}{c}0.253233 \\
(0.828) \\
\end{array}$ \\
\hline Observations & 135 & 135 & 135 \\
\hline $\mathrm{R}$-squared & 0.288 & 0.663 & 0.295 \\
\hline $\begin{array}{l}\text { Partial R-squared of excluded instruments } \\
\text { F-test of excluded instruments } \\
\text { Prob F P } \\
\text { Endogeneity (Stock-Wright) test } \\
\text { (p-value) } \\
\text { Overidentification (Sargan) test } \\
\text { (p-value) }\end{array}$ & & $\begin{array}{c}0.0987 \\
2.60 \\
(0.029)^{* *} \\
3.27 \\
(0.6578) \\
0.925 \\
(0.9209) \\
\end{array}$ & $\begin{array}{c}0.0987 \\
2.60 \\
(0.029)^{* *} \\
3.39 \\
(0.6404) \\
1.910 \\
(0.7524) \\
\end{array}$ \\
\hline
\end{tabular}

$* p<0.1 ; * * p<0.05 ; * * * p<0.01$ 
Table 6: Debt-based Reputational Effects of Credit Ratings around Operational Risk Announcements

This table reports the results of the 2SLS regression model estimating the debt-based reputational impact $\operatorname{CASC}(-5,+5)$ in Model (2) and $\operatorname{CARSC}(-5,+5)$ in Model (3) around operational risk event announcements in publicly listed financial institutions incorporated in USA, Europe, Canada, Australia, and Japan during the postglobal financial crisis (post-GFC) period (2010 - 2014). Model (1) reports the results of the first-stage regression estimating the endogenous variable $\operatorname{RCAR(-5},+5)$. Variables description is reported in the appendix. Heteroscedasticity-robust standard errors and two-tailed t-tests are used to infer the significance of the regression coefficients. $* \mathrm{p}<0.1 ; * * \mathrm{p}<0.05 ; * * * \mathrm{p}<0.01$.

Panel B: Speculative Grade

\begin{tabular}{|c|c|c|c|}
\hline \multirow{3}{*}{ Variables } & \multirow{2}{*}{$\begin{array}{c}\text { First-stage Regression } \\
(1)\end{array}$} & \multicolumn{2}{|c|}{ Second-stage Regression } \\
\hline & & (2) & (3) \\
\hline & $\operatorname{RCAR}(-5,+5)$ & $\operatorname{CASC}(-5,+5)$ & $\operatorname{CARSC}(-5,+5)$ \\
\hline Speculative Grade & $\begin{array}{c}-0.012566 \\
(-0.322)\end{array}$ & $\begin{array}{l}41.076384 \\
(5.730)^{* * *}\end{array}$ & $\begin{array}{c}0.153432 \\
(3.317)^{* * *}\end{array}$ \\
\hline Analyst Coverage & $\begin{array}{c}0.000581 \\
(0.421)\end{array}$ & $\begin{array}{l}-0.186976 \\
(-0.817)\end{array}$ & $\begin{array}{l}-0.000940 \\
(-0.600)\end{array}$ \\
\hline Loss Disclosed Dum & $\begin{array}{c}0.007938 \\
(0.566)\end{array}$ & $\begin{array}{c}0.969042 \\
(0.503)\end{array}$ & $\begin{array}{c}0.018593 \\
(1.123)\end{array}$ \\
\hline Firm Recognized Dum & $\begin{array}{c}-0.026789 \\
(-1.333)\end{array}$ & $\begin{array}{c}2.215556 \\
(0.666)\end{array}$ & $\begin{array}{c}0.004550 \\
(0.180)\end{array}$ \\
\hline Regulatory Announced Dum & $\begin{array}{c}0.001332 \\
(0.105)\end{array}$ & $\begin{array}{c}-1.423967 \\
(-0.796)\end{array}$ & $\begin{array}{l}-0.023137 \\
(-1.734)^{*}\end{array}$ \\
\hline Settlement Dum & $\begin{array}{c}0.020127 \\
(1.076)\end{array}$ & $\begin{array}{l}-5.705293 \\
(-1.761)^{*}\end{array}$ & $\begin{array}{c}-0.031254 \\
(-1.109)\end{array}$ \\
\hline Different Country Dum & $\begin{array}{c}-0.034270 \\
(-1.651)\end{array}$ & $\begin{array}{c}-0.206478 \\
(-0.076)\end{array}$ & $\begin{array}{c}0.002517 \\
(0.113)\end{array}$ \\
\hline Top Figures Dum & $\begin{array}{c}-0.036953 \\
(-0.973)\end{array}$ & $\begin{array}{c}8.439892 \\
(1.343)\end{array}$ & $\begin{array}{c}0.032191 \\
(0.635)\end{array}$ \\
\hline Basel Business Line Dum & $\begin{array}{c}-0.026620 \\
(-1.391)\end{array}$ & $\begin{array}{c}6.406271 \\
(1.696)^{*}\end{array}$ & $\begin{array}{c}0.024464 \\
(1.091)\end{array}$ \\
\hline Fraud Dum & $\begin{array}{c}0.015690 \\
(0.899)\end{array}$ & $\begin{array}{c}-4.747248 \\
(-1.416)\end{array}$ & $\begin{array}{c}-0.028686 \\
(-1.016)\end{array}$ \\
\hline U.S. Firm Dum & $\begin{array}{c}-0.028247 \\
(-1.181)\end{array}$ & $\begin{array}{c}-4.735311 \\
(-1.450)\end{array}$ & $\begin{array}{c}-0.030493 \\
(-1.073)\end{array}$ \\
\hline Ln(Total Assets) & $\begin{array}{l}0.038471 \\
(2.164)^{* *}\end{array}$ & $\begin{array}{c}-3.150611 \\
(-1.105)\end{array}$ & $\begin{array}{c}-0.014981 \\
(-0.728)\end{array}$ \\
\hline$R O A$ & $\begin{array}{c}0.005656 \\
(0.309)\end{array}$ & $\begin{array}{l}5.664808 \\
(2.041)^{* *}\end{array}$ & $\begin{array}{c}0.037849 \\
(1.933)^{*}\end{array}$ \\
\hline Leverage & $\begin{array}{l}0.007435 \\
(0.825)\end{array}$ & $\begin{array}{c}-4.427229 \\
(-2.691)^{* * *}\end{array}$ & $\begin{array}{c}-0.037254 \\
(-3.136)^{* * *}\end{array}$ \\
\hline Market to Book Ratio & $\begin{array}{c}0.025546 \\
(1.373)\end{array}$ & $\begin{array}{c}-1.609140 \\
(-0.498)\end{array}$ & $\begin{array}{c}-0.001372 \\
(-0.063)\end{array}$ \\
\hline GDP Per Capita & $\begin{array}{c}0.000002 \\
(1.294)\end{array}$ & $\begin{array}{c}0.000014 \\
(0.098)\end{array}$ & $\begin{array}{c}0.000000 \\
(0.536)\end{array}$ \\
\hline Buy Stock Recommendation & $\begin{array}{c}-0.012280 \\
(-1.198)\end{array}$ & & \\
\hline StDev Stock Return & $\begin{array}{l}1.594080 \\
(1.656)\end{array}$ & & \\
\hline Beta & $\begin{array}{l}0.024157 \\
(2.043)^{* *}\end{array}$ & & \\
\hline Float & $\begin{array}{c}-0.000042 \\
(-0.102)\end{array}$ & & \\
\hline Ln(Trading Volume) & $\begin{array}{c}-0.005493 \\
(-1.332)\end{array}$ & & \\
\hline$R C A R(-5,+5)$ & & $\begin{array}{l}79.649196 \\
(1.269)\end{array}$ & $\begin{array}{c}0.444985 \\
(1.055)\end{array}$ \\
\hline Constant & $\begin{array}{l}-0.654624 \\
(-2.493)^{* *} \\
\end{array}$ & $\begin{array}{c}51.773134 \\
(1.285) \\
\end{array}$ & $\begin{array}{c}0.254277 \\
(0.860) \\
\end{array}$ \\
\hline $\begin{array}{l}\text { Observations } \\
\text { R-squared }\end{array}$ & $\begin{array}{c}135 \\
0.288\end{array}$ & $\begin{array}{c}135 \\
0.673\end{array}$ & $\begin{array}{c}135 \\
0.302\end{array}$ \\
\hline $\begin{array}{l}\text { Partial R-squared of excluded instruments } \\
\text { F-test of excluded instruments } \\
\text { Prob } \quad \text { F } \\
\text { Endogeneity (Stock-Wright) test } \\
\text { (p-value) } \\
\text { Overidentification (Sargan) test } \\
\text { (p-value) }\end{array}$ & & $\begin{array}{c}0.0982 \\
2.46 \\
(0.0372)^{* *} \\
2.12 \\
(0.8318) \\
0.127 \\
(0.9981) \\
\end{array}$ & $\begin{array}{c}0.0982 \\
2.46 \\
(0.0372) * * \\
3.10 \\
(0.6848) \\
1.703 \\
(0.7902) \\
\end{array}$ \\
\hline
\end{tabular}

$* p<0.1 ; * * p<0.05 ; * * * p<0.01$ 


\section{Table 7: Further Analysis}

This table reports the summarised further analysis results of the OLS regression model estimating the equity-based reputational impact $R C A R(-5,+5)$ in Models $(1)$ and $(3)$, the logit model estimating the log-odds of equity-based reputational damage $\ln \left(\operatorname{odds}\left(R C A R_{i j}(-5,+5)<0\right)\right.$ ) in Models (2) and (4), and the second-stage of the 2 SLS regression model estimating the debt-based reputational impact $\operatorname{CASC}(-5,+5)$ in Models $(5)$ and $(7)$ and $\operatorname{CARSC}(-5,+5)$ in Models $(6)$ and $(8)$ around operational risk event announcements in publicly listed financial institutions incorporated in USA, Europe, Canada, Australia, and Japan during the post-global financial crisis (post-GFC) period $(2010-2014)$. Variables description is reported in the appendix. Heteroscedasticity-robust standard errors and two-tailed t-tests are used to infer the significance of the regression coefficients. $* \mathrm{p}<0.1 ; * * \mathrm{p}<0.05 ; * * \mathrm{p}<0.01$

\section{Panel A: U.S. Firms}

\begin{tabular}{|c|c|c|c|c|c|c|c|c|}
\hline \multirow[b]{2}{*}{ Variables } & (1) & (2) & (3) & (4) & (5) & (6) & (7) & (8) \\
\hline & $\operatorname{RCAR}(-5,+5)$ & $\begin{array}{l}\quad \ln (\text { odds } \\
\left(R C A R_{i j}(-5,+5)\right. \\
<0))\end{array}$ & $\operatorname{RCAR}(-5,+5)$ & $\begin{aligned} & \ln (\text { odds } \\
&\left(R_{C A R_{i j}}(-5,+5)\right. \\
&<0))\end{aligned}$ & $\operatorname{CASC}(-5,+5)$ & $\operatorname{CARSC}(-5,+5)$ & $\operatorname{CASC}(-5,+5)$ & $\operatorname{CARSC}(-5,+5)$ \\
\hline Buy Stock Recommendation & $\begin{array}{c}0.000018 \\
(0.00)\end{array}$ & $\begin{array}{c}0.634918 \\
(1.29)\end{array}$ & & & & & & \\
\hline Buy * U.S. Firm & $\begin{array}{l}-0.026246 \\
(1.39)\end{array}$ & $\begin{array}{c}0.465927 \\
(0.65)\end{array}$ & & & & & & \\
\hline StDev Stock Recommendation & & & $\begin{array}{c}0.127155 \\
(1.67)^{*}\end{array}$ & $\begin{array}{c}-2.790527 \\
(1.74)^{*}\end{array}$ & & & & \\
\hline StDev *U.S. Firm & & & $\begin{array}{c}-0.218457 \\
(2.29)^{* *}\end{array}$ & $\begin{array}{c}4.565852 \\
(1.77)^{*}\end{array}$ & & & & \\
\hline Credit Rating Level & & & & & $\begin{array}{l}10.645433 \\
(6.359)^{* * *}\end{array}$ & $\begin{array}{c}0.039193 \\
(3.649)^{* * *}\end{array}$ & & \\
\hline Credit Rating Level $*$ U.S. Firm & & & & & $\begin{array}{c}1.270897 \\
(1.326)\end{array}$ & $\begin{array}{c}0.008807 \\
(1.172)\end{array}$ & & \\
\hline Speculative Grade & & & & & & & $\begin{array}{l}43.793566 \\
(6.389)^{* * * *}\end{array}$ & $\begin{array}{c}0.165614 \\
(3.561)^{* * *}\end{array}$ \\
\hline Speculative Grade * U.S. Firm & & & & & & & $\begin{array}{c}5.176580 \\
(1.281)\end{array}$ & $\begin{array}{c}0.033502 \\
(1.052)\end{array}$ \\
\hline U.S. Firm Dum & $\begin{array}{c}0.018821 \\
(1.16)\end{array}$ & $\begin{array}{c}-0.537610 \\
(0.92)\end{array}$ & $\begin{array}{l}0.207202 \\
(2.23)^{* *}\end{array}$ & $\begin{array}{c}-4.560683 \\
(1.91)^{*}\end{array}$ & $\begin{array}{c}-5.221835 \\
(-1.329)\end{array}$ & $\begin{array}{c}-0.036802 \\
(-1.097)\end{array}$ & $\begin{array}{l}-4.607548 \\
(-1.403)\end{array}$ & $\begin{array}{c}-0.030611 \\
(-1.080)\end{array}$ \\
\hline R2 & 0.11 & 0.08 & 0.14 & 0.07 & 0.649 & 0.287 & 0.655 & 0.290 \\
\hline $\mathrm{N}$ & 223 & 223 & 223 & 223 & 135 & 135 & 135 & 135 \\
\hline
\end{tabular}

* $p<0.1 ; * * p<0.05 ; * * * p<0.01$ 


\section{Table 7: Further Analysis}

This table reports the summarised further analysis results of the OLS regression model estimating the equity-based reputational impact $R C A R(-5,+5)$ in Models $(1)$ and $(3)$, the logit model estimating the log-odds of equity-based reputational damage $\ln \left(\operatorname{odd} s\left(R C A R_{i j}(-5,+5)<0\right)\right.$ ) in Models (2) and (4), and the second-stage of the $2 \mathrm{SLS}$ regression model estimating the debt-based reputational impact $\operatorname{CASC}(-5,+5)$ in Models $(5)$ and $(7)$ and $\operatorname{CARSC}(-5,+5)$ in Models $(6)$ and $(8)$ around operational risk event announcements in publicly listed financial institutions incorporated in USA, Europe, Canada, Australia, and Japan during the post-global financial crisis (post-GFC) period $(2010$ - 2014). Variables description is reported in the appendix. Heteroscedasticity-robust standard errors and two-tailed t-tests are used to infer the significance of the regression coefficients. $* \mathrm{p}<0.1 ; * * \mathrm{p}<0.05 ; * * * \mathrm{p}<0.01$.

Panel B: Fraud Incidents

\begin{tabular}{|c|c|c|c|c|c|c|c|c|}
\hline \multirow[b]{2}{*}{ Variables } & (1) & (2) & (3) & (4) & (5) & (6) & (7) & (8) \\
\hline & $\operatorname{RCAR}(-5,+5)$ & $\begin{array}{l}\quad \ln (\text { odds } \\
\left(R C A R_{i j}(-5,+5)\right. \\
<0))\end{array}$ & $R C A R(-5,+5)$ & $\begin{array}{l}\quad \ln (\text { odds } \\
\left(R_{C A R_{i j}(-5,+5)}\right. \\
<0))\end{array}$ & $\operatorname{CASC}(-5,+5)$ & $\operatorname{CARSC}(-5,+5)$ & $\operatorname{CASC}(-5,+5)$ & $\operatorname{CARSC}(-5,+5$ \\
\hline Buy Stock Recommendation & $\begin{array}{c}-0.010370 \\
(0.92)\end{array}$ & $\begin{array}{c}0.712295 \\
(1.85)^{*}\end{array}$ & & & & & & \\
\hline Buy $*$ Fraud & $\begin{array}{c}-0.008301 \\
(0.38)\end{array}$ & $\begin{array}{c}1.197924 \\
(1.17)\end{array}$ & & & & & & \\
\hline StDev Stock Recommendation & & & $\begin{array}{c}0.069823 \\
(0.98)\end{array}$ & $\begin{array}{c}-1.618895 \\
(1.04)\end{array}$ & & & & \\
\hline StDev * Fraud & & & $\begin{array}{c}-0.044939 \\
(0.41)\end{array}$ & $\begin{array}{c}1.383312 \\
(0.50)\end{array}$ & & & & \\
\hline Credit Rating Level & & & & & $\begin{array}{l}10.509355 \\
(6.125)^{* * * *}\end{array}$ & $\begin{array}{c}0.038770 \\
(3.670)^{* * * *}\end{array}$ & & \\
\hline Credit Rating Level $*$ Fraud & & & & & $\begin{array}{l}2.150450 \\
(2.083)^{* *}\end{array}$ & $\begin{array}{c}0.011178 \\
(1.465)\end{array}$ & & \\
\hline Speculative Grade & & & & & & & $\begin{array}{l}43.310392 \\
(6.195)^{* * *}\end{array}$ & $\begin{array}{c}0.163619 \\
(3.612)^{* * *}\end{array}$ \\
\hline Speculative Grade * Fraud & & & & & & & $\begin{array}{l}7.863285 \\
(1.821)^{*}\end{array}$ & $\begin{array}{c}0.040881 \\
(1.279)\end{array}$ \\
\hline Fraud Dum & $\begin{array}{c}0.011568 \\
(0.64)\end{array}$ & $\begin{array}{c}-0.781948 \\
(0.98)\end{array}$ & $\begin{array}{c}0.046091 \\
(0.45)\end{array}$ & $\begin{array}{c}-1.406253 \\
(0.54)\end{array}$ & $\begin{array}{l}-6.734044 \\
(-1.697)^{*}\end{array}$ & $\begin{array}{c}-0.039267 \\
(-1.203)\end{array}$ & $\begin{array}{c}-4.870047 \\
(-1.473)\end{array}$ & $\begin{array}{c}-0.029745 \\
(-1.078)\end{array}$ \\
\hline $\mathrm{R} 2$ & 0.10 & 0.08 & 0.11 & 0.06 & 0.645 & 0.292 & 0.655 & 0.298 \\
\hline $\mathrm{N}$ & 223 & 223 & 223 & 223 & 135 & 135 & 135 & 135 \\
\hline
\end{tabular}




\section{Table 7: Further Analysis}

This table reports the summarised further analysis results of the OLS regression model estimating the equity-based reputational impact $R C A R(-5,+5)$ in Models $(1)$ and $(3)$, the logit model estimating the log-odds of equity-based reputational damage $\ln \left(\operatorname{odds}\left(R C A R_{i j}(-5,+5)<0\right)\right.$ ) in Models (2) and (4), and the second-stage of the $2 \mathrm{SLS}$ regression model estimating the debt-based reputational impact $\operatorname{CASC}(-5,+5)$ in Models $(5)$ and $(7)$ and $\operatorname{CARSC}(-5,+5)$ in Models $(6)$ and $(8)$ around operational risk event announcements in publicly listed financial institutions incorporated in USA, Europe, Canada, Australia, and Japan during the post-global financial crisis (post-GFC) period $(2010$ - 2014). Variables description is reported in the appendix. Heteroscedasticity-robust standard errors and two-tailed t-tests are used to infer the significance of the regression coefficients. * $\mathrm{p}<0.1 ; * * \mathrm{p}<0.05 ; * * * \mathrm{p}<0.01$

\begin{tabular}{|c|c|c|c|c|c|c|c|c|}
\hline \multirow[b]{2}{*}{ Variables } & (1) & & (4) & (5) & (6) & $(7)$ & (8) \\
\hline & $\operatorname{RCAR}(-5,+5)$ & $\begin{aligned} & \ln (\text { odds } \\
&\left(R C A R_{i j}(-5,+5)\right. \\
&<0)\end{aligned}$ & $R C A R(-5,+5)$ & $\begin{aligned} & \ln (\text { odds } \\
&\left(R_{C A R_{i j}}(-5,+5)\right. \\
&<0)\end{aligned}$ & $\operatorname{CASC}(-5,+5)$ & $\operatorname{CARSC}(-5,+5)$ & $\operatorname{CASC}(-5,+5)$ & $\operatorname{CARSC}(-5,+5$ \\
\hline Buy Stock Recommendation & $\begin{array}{c}-0.013411 \\
(0.41)\end{array}$ & $\begin{array}{c}1.142254 \\
(1.54)\end{array}$ & & & & & & \\
\hline Buy * Basel & $\begin{array}{c}0.002543 \\
(0.07)\end{array}$ & $\begin{array}{c}-0.377769 \\
(0.46)\end{array}$ & & & & & & \\
\hline StDev Stock Recommendation & & & $\begin{array}{c}0.204507 \\
(1.53)\end{array}$ & $\begin{array}{c}-0.692853 \\
(0.33)\end{array}$ & & & & \\
\hline StDev * Basel & & & $\begin{array}{l}-0.207574 \\
(1.59)\end{array}$ & $\begin{array}{c}-0.789340 \\
(0.33)\end{array}$ & & & & \\
\hline Credit Rating Level & & & & & $\begin{array}{l}12.401650 \\
(7.352) * * *\end{array}$ & $\begin{array}{c}0.048760 \\
(4.214)^{* * *}\end{array}$ & & \\
\hline Credit Rating Level * Basel & & & & & $\begin{array}{l}-2.274609 \\
(-2.202) * *\end{array}$ & $\begin{array}{l}-0.012103 \\
(-1.890)^{*}\end{array}$ & & \\
\hline Speculative Grade & & & & & & & $\begin{array}{l}50.740456 \\
(7.270)^{* * * *}\end{array}$ & $\begin{array}{c}0.197367 \\
(3.944)^{* * *}\end{array}$ \\
\hline Speculative Grade * Basel & & & & & & & $\begin{array}{l}-8.843588 \\
(-1.986)^{* *}\end{array}$ & $\begin{array}{c}-0.038757 \\
(-1.711)^{*}\end{array}$ \\
\hline Basel Business Line Dum & $\begin{array}{c}-0.012408 \\
(0.66) \\
\end{array}$ & $\begin{array}{c}0.245325 \\
(0.45) \\
\end{array}$ & $\begin{array}{c}0.184101 \\
(1.57)\end{array}$ & $\begin{array}{c}0.831024 \\
(0.35) \\
\end{array}$ & $\begin{array}{l}8.066758 \\
(1.869)^{*}\end{array}$ & $\begin{array}{c}0.033914 \\
(1.326) \\
\end{array}$ & $\begin{array}{c}5.558993 \\
(1.537) \\
\end{array}$ & $\begin{array}{c}0.019744 \\
(0.914)\end{array}$ \\
\hline R2 & 0.10 & 0.08 & 0.15 & 0.06 & 0.649 & 0.298 & 0.658 & 0.301 \\
\hline $\mathrm{N}$ & 223 & 223 & 223 & 223 & 135 & 135 & 135 & 135 \\
\hline
\end{tabular}




\section{Table 7: Further Analysis}

This table reports the summarised further analysis results of the OLS regression model estimating the equity-based reputational impact $R C A R(-5,+5)$ in Models $(1)$ and $(3)$, the logit model estimating the log-odds of equity-based reputational damage $\ln \left(\operatorname{odds}\left(R C A R_{i j}(-5,+5)<0\right)\right.$ ) in Models (2) and (4), and the second-stage of the $2 \mathrm{SLS}$ regression model estimating the debt-based reputational impact $\operatorname{CASC}(-5,+5)$ in Models $(5)$ and $(7)$ and $\operatorname{CARSC}(-5,+5)$ in Models $(6)$ and $(8)$ around operational risk event announcements in publicly listed financial institutions incorporated in USA, Europe, Canada, Australia, and Japan during the post-global financial crisis (post-GFC) period $(2010$ - 2014). Variables description is reported in the appendix. Heteroscedasticity-robust standard errors and two-tailed t-tests are used to infer the significance of the regression coefficients. $* \mathrm{p}<0.1 ; * * \mathrm{p}<0.05 ; * * * \mathrm{p}<0.01$.

Panel D: Top Figures

\begin{tabular}{|c|c|c|c|c|c|c|c|c|}
\hline \multirow[b]{2}{*}{ Variables } & (1) & (2) & (3) & (4) & (5) & (6) & (7) & (8) \\
\hline & $R C A R(-5,+5)$ & $\begin{array}{l}\quad \ln (\text { odds } \\
\left(\operatorname{RCAR}_{i j}(-5,+5)\right. \\
<0))\end{array}$ & $R C A R(-5,+5)$ & $\begin{aligned} & \ln (\text { odds } \\
&\left(\operatorname{RCAR}_{i j}(-5,+5)\right. \\
&<0))\end{aligned}$ & $\operatorname{CASC}(-5,+5)$ & $\operatorname{CARSC}(-5,+5)$ & $\operatorname{CASC}(-5,+5)$ & $\operatorname{CARSC}(-5,+5)$ \\
\hline $\begin{array}{l}\text { Buy Stock Recommendation } \\
\text { Buy*Top Figures }\end{array}$ & $\begin{array}{c}-0.015849 \\
(1.69)^{*} \\
0.101297\end{array}$ & $\begin{array}{c}0.895566 \\
(2.40)^{* *} \\
-1.557976\end{array}$ & & & & & & \\
\hline StDev Stock Recommendation & $(1.17)$ & $(1.11)$ & -0.026497 & -0.437111 & & & & \\
\hline StDev $*$ Top Figures & & & $\begin{array}{l}0.414591 \\
(2.39)^{* *}\end{array}$ & $\begin{array}{l}-5.997749 \\
(2.19) * *\end{array}$ & & & & \\
\hline Credit Rating Level & & & & & $\begin{array}{l}11.009996 \\
(6.769)^{* * * *}\end{array}$ & $\begin{array}{c}0.041232 \\
(3.938) * * *\end{array}$ & & \\
\hline Credit Rating Level $*$ Top Figures & & & & & $\begin{array}{c}-1.645419 \\
(-1.220)\end{array}$ & $\begin{array}{c}-0.005082 \\
(-0.457)\end{array}$ & & \\
\hline Speculative Grade & & & & & & & $\begin{array}{l}44.951182 \\
(6.809)^{* * * *}\end{array}$ & $\begin{array}{c}0.172262 \\
(3.823)^{* * *}\end{array}$ \\
\hline Speculative Grade * Top Figures & & & & & & & $\begin{array}{c}-6.483567 \\
(-1.099)\end{array}$ & $\begin{array}{c}-0.021211 \\
(-0.433)\end{array}$ \\
\hline Top Figures Dum & $\begin{array}{c}-0.057249 \\
(1.80)^{*}\end{array}$ & $\begin{array}{c}-0.066644 \\
(0.06)\end{array}$ & $\begin{array}{l}-0.381807 \\
(2.85) * * *\end{array}$ & $\begin{array}{l}4.510589 \\
(1.69)^{*}\end{array}$ & $\begin{array}{c}8.608418 \\
(1.379) \\
\end{array}$ & $\begin{array}{c}0.029642 \\
(0.551)\end{array}$ & $\begin{array}{c}6.515639 \\
(1.199)\end{array}$ & $\begin{array}{c}0.023021 \\
(0.489)\end{array}$ \\
\hline R2 & 0.13 & 0.08 & 0.22 & 0.07 & 0.669 & 0.304 & 0.679 & 0.311 \\
\hline $\mathrm{N}$ & 223 & 223 & 223 & 223 & 135 & 135 & 135 & 135 \\
\hline
\end{tabular}


Table 8: Robustness Checks

This table reports the summarised robustness check results of the OLS regression model estimating the equity-based reputational impact $R C A R(-5,+5)$ in Models (1) and (3), the logit model estimating the log-odds of equity-based reputational damage $\ln \left(\operatorname{odd} s\left(R C A R_{i j}(-5,+5)<0\right)\right)$ in Models $(2)$ and $(4)$, and the second-stage of the $2 S L S$ regression model estimating the debt-based reputational impact $C A S C(-5,+5)$ in Models $(5)$ and $(7)$ and $C A R S C(-5,+5)$ in Models $(6)$ and $(8)$ around operational risk event announcements in publicly listed financial institutions incorporated in USA, Europe, Canada, Australia, and Japan during the post-global financial crisis (post-GFC) period $(2010$ - 2014). In computing $(R C A R(-5,+5))$, the ex post (settlement) loss amount is used as a correction for all events in our final sample. Other variables description is reported in the appendix. Heteroscedasticity-robust standard errors and two-tailed t-tests are used to infer the significance of the regression coefficients. $* \mathrm{p}<0.1 ; * * \mathrm{p}<0.05$; $* * * \mathrm{p}<0.01$

Panel A: Settlement Loss Amount as a Correction for All Events

\begin{tabular}{|c|c|c|c|c|c|c|c|c|}
\hline \multirow[b]{2}{*}{ Variables } & (1) & (2) & (3) & (4) & (5) & (6) & (7) & (8) \\
\hline & $\operatorname{RCAR}(-5,+5)$ & $\begin{array}{l}\quad \ln (\text { odds } \\
\left(\operatorname{RCAR}_{i j}(-5,+5)\right. \\
<0))\end{array}$ & $R C A R(-5,+5)$ & $\begin{array}{l}\quad \ln (\text { odds } \\
\left(\text { RCAR }_{i j}(-5,+5)\right. \\
<0))\end{array}$ & $\operatorname{CASC}(-5,+5)$ & $\operatorname{CARSC}(-5,+5$ & $\operatorname{CASC}(-5,+5)$ & $\operatorname{CARSC}(-5,+5$ \\
\hline $\begin{array}{l}\text { Buy Stock Recommendation } \\
\text { StDev Stock Recommendation } \\
\text { Credit Rating Level } \\
\text { Speculative Grade }\end{array}$ & $\begin{array}{c}-0.010932 \\
(1.00)\end{array}$ & $\begin{array}{c}0.830422 \\
(2.26) * *\end{array}$ & $\begin{array}{c}0.050915 \\
(0.87)\end{array}$ & $\begin{array}{c}-0.655843 \\
(0.54)\end{array}$ & $\begin{array}{l}10.915079 \\
(6.653)^{* * * *}\end{array}$ & $\begin{array}{c}0.040967 \\
(3.901)^{* * * *}\end{array}$ & $\begin{array}{l}44.855220 \\
(6.705) * * *\end{array}$ & $\begin{array}{c}0.172093 \\
(3.807) * * *\end{array}$ \\
\hline $\begin{array}{l}\mathrm{R} 2 \\
\mathrm{~N}\end{array}$ & $\begin{array}{l}0.10 \\
223\end{array}$ & $\begin{array}{l}0.06 \\
223\end{array}$ & $\begin{array}{l}0.10 \\
223\end{array}$ & $\begin{array}{l}0.05 \\
223\end{array}$ & $\begin{array}{l}0.66 \\
135\end{array}$ & $\begin{array}{l}0.30 \\
135\end{array}$ & $\begin{array}{c}0.67 \\
135\end{array}$ & $\begin{array}{c}0.31 \\
135\end{array}$ \\
\hline
\end{tabular}

$* p<0.1 ; * * p<0.05 ; * * * p<0.01$ 
Table 8: Robustness Checks

This table reports the summarised robustness check results of the OLS regression model estimating the equity-based reputational impact $R C A R(-5,+5)$ in Models (1) and (3), the logit model estimating the log-odds of equity-based reputational damage $\ln \left(\operatorname{odd} s\left(R C A R_{i j}(-5,+5)<0\right)\right)$ in Models $(2)$ and $(4)$, and the second-stage of the $2 S L S$ regression model estimating the debt-based reputational impact $C A S C(-5,+5)$ in Models $(5)$ and $(7)$ and $C A R S C(-5,+5)$ in Models $(6)$ and $(8)$ around operational risk event announcements in publicly listed financial institutions incorporated in USA, Europe, Canada, Australia, and Japan during the post-global financial crisis (post-GFC) period (2010 - 2014). Lag is the number of days since the most recent credit rating update. Other variables description is reported in the appendix. Heteroscedasticity-robust standard errors and two-tailed t-tests are used to infer the significance of the regression coefficients. $* \mathrm{p}<0.1 ; * * \mathrm{p}<0.05 ; * * * \mathrm{p}<0.01$.

Panel B: Time Elapsed Since Last Credit Rating Update

\begin{tabular}{|c|c|c|c|c|c|c|c|c|}
\hline \multirow[b]{2}{*}{ Variables } & (1) & (2) & (3) & (4) & (5) & (6) & (7) & (8) \\
\hline & $\operatorname{RCAR}(-5,+5)$ & $\begin{array}{l}\quad \ln (\text { odds } \\
\left(R_{C A R_{i j}}(-5,+5)\right. \\
<0))\end{array}$ & $\operatorname{RCAR}(-5,+5)$ & $\begin{array}{l}\quad \ln (\text { odds } \\
\left(R C A R_{i j}(-5,+5)\right. \\
<0))\end{array}$ & $\operatorname{CASC}(-5,+5)$ & $\operatorname{CARSC}(-5,+5)$ & $\operatorname{CASC}(-5,+5)$ & $\operatorname{CARSC}(-5,+5)$ \\
\hline Credit Rating Level & $\begin{array}{l}-0.009077 \\
(2.65) * * *\end{array}$ & $\begin{array}{c}1.240572 \\
(3.85)^{* * * *}\end{array}$ & & & $\begin{array}{c}9.923100 \\
(5.075) * * *\end{array}$ & $\begin{array}{c}0.043481 \\
(3.420)^{* * *}\end{array}$ & & \\
\hline Credit Rating Level * Lag & $\begin{array}{l}0.000012 \\
(2.56)^{* *}\end{array}$ & $\begin{array}{c}-0.001668 \\
(4.17)^{* * *}\end{array}$ & & & $\begin{array}{c}0.003951 \\
(0.937)\end{array}$ & $\begin{array}{c}-0.000004 \\
(-0.110)\end{array}$ & & \\
\hline Speculative Grade & & & $\begin{array}{l}-0.105209 \\
(2.97) * * *\end{array}$ & $\begin{array}{l}16.676859 \\
(4.60) * * * *\end{array}$ & & & $\begin{array}{l}36.682414 \\
(4.458)^{* * * *}\end{array}$ & $\begin{array}{c}0.144270 \\
(2.719)^{* * * *}\end{array}$ \\
\hline Speculative Grade * Lag & & & $\begin{array}{l}0.000146 \\
(3.09)^{* * *}\end{array}$ & $\begin{array}{l}-0.028645 \\
(3.84)^{* * * *}\end{array}$ & & & $\begin{array}{c}0.028382 \\
(1.190)\end{array}$ & $\begin{array}{c}0.000111 \\
(1.031)\end{array}$ \\
\hline Lag & $\begin{array}{c}0.000007 \\
(0.53)\end{array}$ & $\begin{array}{l}0.001223 \\
(2.05)^{* *}\end{array}$ & $\begin{array}{c}0.000017 \\
(1.27)\end{array}$ & $\begin{array}{c}-0.000201 \\
(0.45)\end{array}$ & $\begin{array}{c}-0.002406 \\
(-0.543)\end{array}$ & $\begin{array}{c}0.000021 \\
(0.586)\end{array}$ & $\begin{array}{c}-0.001436 \\
(-0.493)\end{array}$ & $\begin{array}{c}0.000012 \\
(0.528) \\
\end{array}$ \\
\hline R2 & 0.15 & 0.14 & 0.15 & 0.19 & 0.657 & 0.261 & 0.680 & 0.281 \\
\hline $\mathrm{N}$ & 223 & 223 & 223 & 223 & 135 & 135 & 135 & 135 \\
\hline
\end{tabular}


Appendix A: Variables Description

\begin{tabular}{|c|c|c|}
\hline Variable Name & Definition & Data Source(s) \\
\hline$R C A R(-5,+5)$ & $\begin{array}{l}\text { Reputational return in the event window }(-5,+5)=\text { Cumulative abnormal stock return }+\mid(\text { Operational loss } \\
\text { amount / Market value of the loss firm one calendar week before the announcement date }) \mid \\
\text { Cumulative abnormal stock return in the event window }(-5,+5)=\sum_{i=-5}^{5} \text { Abnormal Stock Return }_{i} \text {, where } \\
\text { Abnormal Stock Return } n_{i}=\text { Firm Stock Return } \text { R }_{i}-\text { Normal Stock Return }_{i} \text { Estimation window of the } \\
\text { normal stock return is } 250 \text { trading days ending one calendar month before the announcement date. Estimation } \\
\text { model is single-factor market model. Original stock prices are measured in US dollar. }\end{array}$ & $\begin{array}{l}\text { - DataStream } \\
\text { - ORIC } \\
\text { - LexisNexis }\end{array}$ \\
\hline $\operatorname{Pr}\left(R C A R_{i j}(-5,+5)<0\right)$ & 1 if reputational return is negative in the event window $(-5,+5) ; 0$ otherwise & $\begin{array}{l}\text { - DataStream } \\
\text { - ORIC } \\
\text { - LexisNexis }\end{array}$ \\
\hline $\operatorname{CASC}(-5,+5)$ & 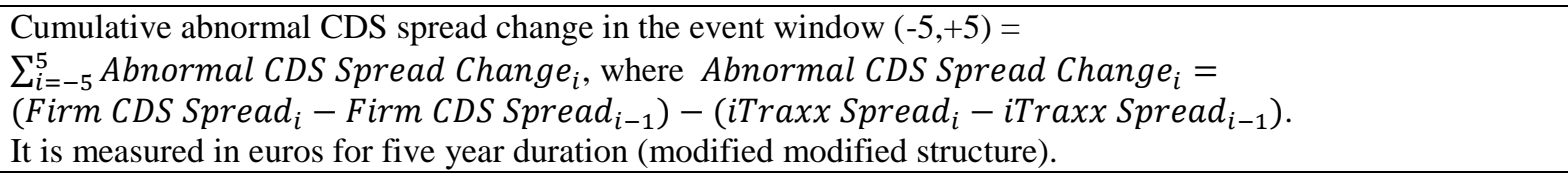 & DataStream \\
\hline$C A R S C(-5,+5)$ & 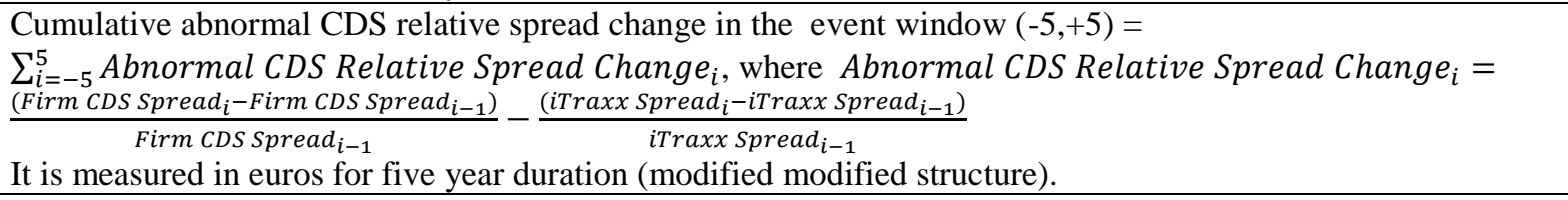 & DataStream \\
\hline Buy Stock Recommendation & $\begin{array}{l}1 \text { if the median of most recent consensus stock analyst recommendations before the announcement date is } \\
\text { "Buy" Recommendation; } 0 \text { otherwise }\end{array}$ & Bloomberg \\
\hline StDev Stock Recommendation & Standard deviation of most recent consensus stock analyst recommendations before the announcement date & Bloomberg \\
\hline Credit Rating Level & $\begin{array}{l}\text { Global corporate average cumulative default rate (five-year horizon) of Standard \& Poor's (S\&P) long-term } \\
\text { local issuer credit rating from } 1981 \text { to the year preceding the operational risk event announcement date. Data } \\
\text { on transition matrices are collected from the "Annual Global Corporate Default Study And Rating Transitions" } \\
\text { reports published annually by S\&P Global. }\end{array}$ & Bloomberg \\
\hline Speculative Grade & $\begin{array}{l}1 \text { if the most recent credit rating before the operational risk event announcement date is BB+ or lower; } 0 \\
\text { otherwise }\end{array}$ & Bloomberg \\
\hline Analyst Coverage & Number of equity analysts following the firm (i.e. issuing EPS estimates) & Bloomberg \\
\hline Loss Disclosed Dum & 1 if the operational loss amount is disclosed; 0 otherwise & $\begin{array}{l}\text { - ORIC } \\
\text { - LexisNexis }\end{array}$ \\
\hline Firm Recognized Dum & 1 if the operational risk event is recognised by the loss firm; 0 otherwise & $\begin{array}{l}\text { - ORIC } \\
\text { - LexisNexis }\end{array}$ \\
\hline Regulatory Announced Dum & 1 if the operational risk event is announced by a regulatory body; 0 otherwise & $\begin{array}{l}\text { - ORIC } \\
\text { - LexisNexis }\end{array}$ \\
\hline
\end{tabular}




\begin{tabular}{|c|c|c|}
\hline Settlement Dum & 1 if the operational risk event is settled; 0 otherwise & $\begin{array}{l}\text { - ORIC } \\
\text { - LexisNexis }\end{array}$ \\
\hline Different Country Dum & $\begin{array}{l}1 \text { is the operational risk event takes place in a country different from the loss firm headquarters' country; } 0 \\
\text { otherwise }\end{array}$ & $\begin{array}{l}\text { - ORIC } \\
\text { - LexisNexis }\end{array}$ \\
\hline Top Figures Dum & $\begin{array}{l}1 \text { if the operational risk event directly involves one or more of the board directors or chief executives; } 0 \\
\text { otherwise }\end{array}$ & $\begin{array}{l}\text { - ORIC } \\
\text { - LexisNexis }\end{array}$ \\
\hline Basel Business Line Dum & $\begin{array}{l}1 \text { id the operational risk event is classified under one of the eight Basel II business lines: Corporate finance, } \\
\text { trading and sales, retail banking, commercial banking, payment and settlement, agency services, asset } \\
\text { management, retail Brokerage; } 0 \text { otherwise }\end{array}$ & $\begin{array}{l}\text { - ORIC } \\
\text { - LexisNexis }\end{array}$ \\
\hline Fraud Dum & 1 if the operational risk event is classified as internal fraud or external fraud; 0 otherwise & $\begin{array}{l}\text { - ORIC } \\
\text { - LexisNexis }\end{array}$ \\
\hline U.S. Firm Dum & 1 if the operational risk event is incurred by a U.S. firm; 0 otherwise & $\begin{array}{l}\text { - ORIC } \\
\text { - LexisNexis }\end{array}$ \\
\hline StDev Stock Return & $\begin{array}{l}\text { Standard deviation of daily stock returns for one trading year ending one calendar month before the } \\
\text { announcement date }\end{array}$ & DataStream \\
\hline Beta & Monthly stock's beta (measured at the end of calendar month preceding the announcement date) & DataStream \\
\hline Float & $\begin{array}{l}\text { The percentage of outstanding shares available to ordinary shareholders one week before the announcement } \\
\text { date }\end{array}$ & DataStream \\
\hline Trading Volume & $\begin{array}{l}\text { The natural logarithm of the number of shares traded for the stock (in thousands) one week before the } \\
\text { announcement date }\end{array}$ & DataStream \\
\hline Total Assets & $\begin{array}{l}\text { Natural logarithm of total assets (in millions of US dollar) measured at the end of calendar quarter preceding } \\
\text { the announcement date }\end{array}$ & DataStream \\
\hline$R O A$ & Return on assets $(\%)$ & DataStream \\
\hline Leverage & Long-term debt / Shareholders' equity (Decimals) & DataStream \\
\hline Market to Book Ratio & Market value of equity / Book value of equity (Decimals) & DataStream \\
\hline GDP Per Capita & GDP per capita (in US dollar) & World Bank \\
\hline
\end{tabular}




\section{Appendix B: Credit Rating Transition Matrix}

This transition matrix summarises the global corporate average cumulative default rates (five-year horizon) of Standard \& Poor's (S\&P) long-term local issuer credit ratings from 1981 to the years 2009 - 2013 (i.e. the years preceding the operational risk event announcement dates in our sample). Data on transition matrices are collected from the "Annual Global Corporate Default Study And Rating Transitions" reports published annually by S\&P Global. The default rates are presented in percentages (\%).

\begin{tabular}{|c|c|c|c|c|c|}
\hline Credit Rating & $\mathbf{2 0 0 9}$ & $\mathbf{2 0 1 0}$ & $\mathbf{2 0 1 1}$ & $\mathbf{2 0 1 2}$ & $\mathbf{2 0 1 3}$ \\
\hline AAA & 0.39 & 0.38 & 0.37 & 0.36 & 0.35 \\
\hline AA+ & 0.19 & 0.19 & 0.19 & 0.18 & 0.17 \\
\hline AA & 0.25 & 0.36 & 0.39 & 0.39 & 0.38 \\
\hline AA- & 0.46 & 0.44 & 0.42 & 0.40 & 0.39 \\
\hline A+ & 0.64 & 0.61 & 0.58 & 0.55 & 0.53 \\
\hline A & 0.68 & 0.64 & 0.63 & 0.59 & 0.57 \\
\hline A- & 0.87 & 0.80 & 0.76 & 0.71 & 0.69 \\
\hline BBB+ & 1.63 & 1.51 & 1.43 & 1.33 & 1.27 \\
\hline BBB & 1.98 & 1.89 & 1.82 & 1.73 & 1.69 \\
\hline BBB- & 4.38 & 4.29 & 4.03 & 3.81 & 3.51 \\
\hline BB+ & 5.51 & 5.27 & 5.01 & 4.74 & 4.56 \\
\hline BB & 9.22 & 8.74 & 8.32 & 8.05 & 7.66 \\
\hline BB- & 12.14 & 11.52 & 10.96 & 10.75 & 10.33 \\
\hline B+ & 18.29 & 17.80 & 17.14 & 16.47 & 16.05 \\
\hline B & 25.09 & 24.40 & 22.87 & 22.04 & 21.02 \\
\hline B- & 31.05 & 30.00 & 28.76 & 27.98 & 26.93 \\
\hline CCC/C & 48.05 & 47.64 & 46.72 & 46.64 & 46.75 \\
\hline
\end{tabular}

